\title{
Sepucuk surat dari seorang bangsawan Gowa di tanah pembuangan (Ceylon)
}

\author{
SURYADI
}

\begin{abstract}
This paper looks at an early nineteenth-century Malay letter from a land of exile, Ceylon (present Sri Lanka). The letter, written in Colombo, was dated 3 January 1807 and is in Leiden University Library MS Cod.Or.2241-I 25 [Klt 21/no.526]. It was written by Siti Hapipa, the widow of the exiled Sultan Fakhruddin Abdul Khair al-Mansur Baginda Usman Batara Tangkana Gowa, the 26th king of the Gowa Sultanate of South Sulawesi who reigned from 1753 until 1767. He was banished by the Dutch (Vereenigde Oost-Indische Compagnie, VOC) to Ceylon in 1767 on a charge of conspiracy with the British to oppose the VOC trading monopoly in eastern Indonesia. Although many studies of Malay letters exist, letters from the lands of exile like such as the one discussed in this article have received less scholarly attention. Also remarkable is that this is one of the rare eighteenth- and nineteenth-centuries Malay letters written by a female. Setting the scene with a historical sketch of the eighteenth and the early nineteenth century in colonial Ceylon and the Netherlands East Indies, this paper provides the transliteration of Siti Hapipa's letter in Roman script, through which I then analyse the socio-economic and political aspects of the family of Sultan Fakhruddin in their exile in Colombo.

KEYWORDS

Sastra Melayu lama, surat, Aksara Jawi, orang buangan, kolonialisme, VOC, Inggris, the Ceylon Rifle Regiment, Sultan Fakhruddin, Siti Hapipa, Gowa, Sulawesi Selatan, Colombo, Ceylon.
\end{abstract}

SURYADI adalah pengajar pada Department of Languages and Cultures of Southeast Asia and Oceania, Leiden University, Belanda; berminat pada tradisi lisan, fenomena budaya media di Indonesia, Sastra Indonesia, dan Sastra Melayu Lama. Tulisannya yang terakhir antara lain "The 'talking machines' comes to the Dutch East Indies: the arrival of Western media technology in Southeast Asia", Bijdragen tot de Taal-, Land- en Volkenkunde 162-2/3 (2006): 269-305, dan "Warkah-warkah Sultan Buton Muhyiuddin Abdul Gafur kepada Kompeni Belanda, koleksi Universiteitsbibliotheek Leiden", Sari 25 (2007): 187-239. E-mail: s.suryadi@let.leidenuniv.nl. 
Kisah pembuangan - yang sering diperhalus dengan istilah 'pengasingan' - adalah bagian dari sejarah kolonialisme Eropa zaman lampau. ${ }^{1}$ Banyak pemimpin pribumi - bangsawan lokal dan nasionalis produk sistem pendidikan Barat - dibuang Belanda ke daerah lain, baik dalam wilayah Hindia-Belanda sendiri maupun negeri-negeri di luar Kepulauan Nusantara. Tujuannya adalah untuk memutus pengaruh para pemimpin lokal tersebut di kalangan rakyatnya karena mereka dianggap berbahaya bagi kelangsungan hegemoni sang kolonialis yang terus ingin menguasai koloni mereka. Orangorang yang dibuang itu berasal dari berbagai lapisan sosial dalam masyarakat pribumi - dari raja atau pangeran sampai kepada pemimpin desa. Syekh Yusuf al-Makassari, Sultan Abulfath Mohammad Syifa Zainularifin, Imam Bonjol, Pangeran Dipanegara, Sultan Alam Bagagarsyah, Cut Nyak Din, Sutan Syahrir, Sukarno, dan Muhammad Hatta adalah contoh dari pemimpin pribumi yang pernah mengalami pembuangan di zaman kolonial.

Pada masa yang lebih awal, sebelum munculnya gerakan nasionalisme di Hindia-Belanda, kepergian seorang pemimpin pribumi ke tanah pembuangan dapat dikatakan sebagai awal dari suatu 'penghilangan'. Seringkali mereka yang akan dibuang itu dipaksa pergi dengan terburu-buru tanpa sempat berpamitan dengan keluarga dan sanak-famili mereka. Bahkan untuk bertukar pakaian pun mereka tidak diberi kesempatan, seperti dicatat oleh Tuanku Imam Bonjol dalam Memoir-nya (Nain 2004: 152-153). Seringkali tidak ada kabar apapun lagi setelah orang-orang buangan sampai di negeri pembuangan. Aliran informasi mengenai orang-orang buangan itu ke daerah asal masing-masing sengaja diputus oleh pihak penguasa kolonial Belanda agar mereka dilupakan oleh masyarakat dan para pengikutnya.

Belum ditemukan kajian yang mendalam mengenai kehidupan para orang buangan (atau eksil, selanjutnya istilah 'eksil' ini yang dipakai dalam teks) zaman kolonial itu. Kecuali informasi fragmentaris tentang kemana mereka dibuang, selebihnya tak banyak catatan tentang kehidupan mereka di tanah pembuangan yang terungkap dalam buku-buku sejarah. Demikianlah umpamanya, jarang diketahui bagaimana pandangan mereka terhadap masyarakat dan budaya daerah tempat mereka dibuang; bagaimana mereka menyesuaikan diri dengan masyarakat setempat; bagaimana hubungan mereka dengan penguasa di tanah buangan; bagaimana mereka membiayai hidup mereka beserta keluarga masing-masing di tanah pembuangan; dan bagaimana ingatan mereka terhadap tanah kelahiran sendiri.

Salah satu jenis dokumen sejarah yang merefleksikan pikiran dan emosi para eksil itu adalah surat-surat yang mereka tulis sendiri yang ditujukan kepada Gubernur Jenderal Hindia-Belanda di Batavia. Meskipun sudah banyak kajian yang dibuat mengenai (per)surat(an) Melayu lama, surat-surat dari tanah pembuangan belum banyak dibicarakan, bahkan terkesan sedikit terlupakan. Jumlahnya memang tidak banyak - oleh karena itu mungkin

Atas biaya De Stichting Oosters Instituut saya dapat mempresentasikan versi awal artikel ini pada Simposium Internasional Pernaskahan Nusantara 12 di Universitas Padjajaran, Bandung, 4-7 Agustus 2008. Terima kasih kepada Annabel Teh Gallop, Henri Chambert-Loir, Ian Proudfoot, dan Oman Fathurahman atas catatan dan komentar yang berguna untuk artikel ini. 
luput dari perhatian para peneliti - tetapi isinya tentu sangat menarik dan penting untuk diketahui karena surat-surat tersebut mengandung berbagai informasi yang berharga mengenai kehidupan orang-orang yang dibuang Belanda di negeri asing tempat mereka menjalani sisa hidupnya, bahkan tak jarang berkubur di sana.

Artikel ini akan membahas sepucuk surat dari seorang bangsawan Gowa yang dibuang Belanda (VOC/Vereenigde Oost-Indische Compagnie) ke Colombo ${ }^{2}$, ibukota Ceylon (sekarang Sri Lanka) ${ }^{3}$, pada tahun 1667. ${ }^{4}$ Surat itu adalah Cod.Or.2241-I 25 [Klt 21/no.526] koleksi Universiteitsbibliotheek Leiden, Belanda. Menurut Wieringa (1998: 391) Cod.Or.2241-I 25 [Klt 21/ no.526] adalah "[...] letter from Sitti Hapipa at Ceylon, widow of the exiled Sultan Fakhruddin of Go[w]a, to the Governor General and the Raad van Indië, dated Kolombo, 3 Januari 1807; received at Batavia 29 May 1807". Saya memilih membahas surat ini mengingat bahwa surat-surat Melayu lama yang ditulis perempuan, apalagi dalam pembuangan, jauh lebih sedikit daripada yang ditulis laki-laki (lihat Kratz 2006).

Artikel ini menyajikan transliterasi surat Sitti Hapipa (selanjutnya akan ditulis Siti, mengikuti ejaan sekarang) dan membicarakan isinya serta beberapa aspek mengenai bahasa dan tulisannya. Artikel ini juga akan mendeskripsikan latar belakang historis mengapa Sultan Fakhruddin dibuang oleh Belanda (VOC) ke Ceylon. Diharapkan hasil transliterasi ini dapat dibaca oleh kalangan yang lebih luas di luar mereka yang bisa membaca aksara Jawi. Mengingat kandungan data historis yang dimiliki surat ini, transliterasi itu tentu dapat pula dimanfaatkan oleh peneliti di luar bidang ilmu filologi dan sastra Melayu lama, khususnya sejarawan yang - sejauh saya ketahui - jarang yang mampu membaca sumber-sumber sejarah pribumi yang ditulis dalam aksara Jawi. Isi surat Siti Hapipa (lihat transliterasi) memberikan sejumlah informasi akurat mengenai kehidupan Sultan Fakhruddin beserta keluarga besarnya (dengan dua belas orang anak dan cucu-cucu) di Colombo, tarikh (jam, hari, tanggal, dan tahun) mangkatnya, dan penyebab kematiannya di ibukota Ceylon itu suatu informasi yang cukup terperinci tentang anggota dinasti Kerajaan Gowa yang selama ini belum pernah diungkapkan dalam buku-buku sejarah.

2 Ditulis demikian seperti umum dikenal secara internasional, kecuali dalam kutipan langsung dari suatu referensi dan juga dalam transliterasi Cod.Or.2241-I 25 [Klt 21/no.526] ditulis Kolombo dengan pertimbangan bahwa dalam transliterasi naskah beraksara Jawi huruf Arab kaf biasanya dipadankan dengan huruf Latin $k$.

3 Saya memakai istilah Ceylon, bukan Sri Lanka, nama yang dipakai setelah negara itu memperoleh kemerdekaan dari Inggris pada 4 Febrari 1948. Pertimbangan lainnya adalah bahwa dalam surat yang dibicarakan ini sering muncul nama Selong yang merupakan pelafalan dalam Bahasa Melayu untuk Ceylon (lihat transliterasi).

Studi ini bagian dari penelitian saya tentang empat surat Melayu dari Ceylon. Tiga surat lainnya adalah Cod.Or.2240-Ia 11 [no.71]: Surat Prins Meor Bacan Sadar Alam (Sadaralam) beserta dengan Gugugu< $>$ > Bacan Kaicil Naimuddin, 1792; Cod.Or.2241-I 23 [Klt 22/no.520]: Surat Pangeran Mas Dipati Mangkurat dari Jawa Tengah, 1806; dan Cod. Or.2241-I 24 [Klt 22/no.521]: Surat Raden Tumenggung Wirakusuma dari Surakarta, 1806. Semua surat itu ditujukan kepada Gubernur Jenderal Hindia-Belanda dan Raad van Indië di Batavia (Wieringa 1998: 365, 391). 


\section{SULTAN FAKHRUDDIN DAN LATAR BELAKANG PEMBUANGANNYA}

Fakhruddin Abdul Khair adalah Sultan Gowa ke-26 yang berkuasa tahun 1753-1767. Ia lahir tahun 1747 - sumber lain menyebut dia lahir di Gowa tahun 1649 (lihat uraian di bawah) - dan mangkat dalam pembuangan di Colombo (Ceylon) tahun 1795. Surat Siti Hapipa, istrinya, yang dibicarakan ini menjelaskan tempat, waktu, dan penyebab kematian Sultan Fakhruddin di Colombo.

Nama kecil Sultan Fakhruddin adalah Usman Amas Madina. Ia adalah anak sulung Sultan Gowa ke-25, Abdul Quddus alias I Mappababbasa (17421753), dari hasil perkawinannya dengan Karaeng Ballasari. Istrinya ini adalah putri pasangan Sultan Bima, Alauddin Muhammad Syah ${ }^{5}$, dengan Karaeng Tanasanga, Putri Sultan Gowa ke-21 yang bernama Sirajuddin Tumenanga ri Pasi alias I Mappaurrangi (1711-1713). Sultan Abdul Quddus mendadak mangkat tahun 1753. Konon ia mati karena diracun. Pada 21 Desember 1753 Dewan Bate Salapanga (Dewan Menteri Gowa) memilih Sulaiman Amas Madina sebagai Sultan Gowa yang baru. Karena masih terlalu muda (waktu itu umurnya baru kira-kira 7 tahun), Amas Madina memerintah dengan sistem perwalian. Untuk menjalankan roda pemerintahan Kerajaan Gowa, sultan yang masih kanak-kanak itu diwakili oleh neneknya, Mangkasu mang Karaeng Lempangan. Dalam bulan Juni 1758, Dewan Bate Salapanga memberi gelar "Batara Gowa" kepada Amas Madina, sesuai dengan adat kebiasaan di Gowa. Maksudnya, semoga Sultan yang masih sangat muda itu nantinya dapat mengembalikan keagungan Kerajaan Gowa seperti ketika berada di bawah kekuasaan Batara Gowa (Raja Gowa ketujuh, tahun 1400-an). Pada waktu itu Kerajaan Gowa merdeka dan berdaulat penuh sehingga dapat mencapai puncak kejayaannya.

Mangkubumi Karaeng Lempangan wafat dalam tahun 1760. Ia digantikan oleh saudaranya I Temasongeng Karaeng Katangka. Perwalian terhadap Amas Madina berakhir pada 29 Oktober 1765 ketika Dewan Bate Salapanga secara resmi melantiknya menjadi Sultan Gowa dengan gelar Khalifah alSultan Fakhruddin Abdul Khair al-Mansur Baginda Usman Batara Tangkana Gowa (berarti waktu itu Amas Madina sudah berumur 18 tahun). Akan tetapi, rupanya Sultan Fakhruddin mengalami banyak kekecewaan dalam menjalankan tugas pemerintahannya. Ia menghadapi banyak persoalan dengan keluarga sendiri dan juga dengan Belanda yang sering menekannya secara politis. Pada 12 Agustus 1766, Sultan Fakhruddin meninggalkan istananya dan pergi ke Bima, tanah kelahiran ibunya. Para petinggi Kerajaan Gowa gagal membujuknya untuk tetap tinggal di Gowa.

Belanda (VOC) yang terus berusaha mengendalikan Gowa menuduh Sultan Fakhruddin menjalin hubungan rahasia dengan Inggris. Pada waktu itu, kompetisi antara VOC dan Serikat Dagang Inggris (EIC, the East India

$5 \quad$ Alauddin Muhammad Syah (lahir 1706, mangkat 1748; berkuasa 1731-1748) adalah Sultan Bima keenam. Sultan Alauddin Muhammad Syah mengawini Karaeng Tanasanga tahun 1727 (Haris 2006: 30). Perkawinan antara bangsawan Bima dan Gowa sering terjadi karena secara politik dan agama (Islam) Bima berada dalam pengaruh Gowa. Hubungan itu berubah setelah Gowa ditaklukkan VOC yang secara resmi ditetapkan lewat Perjanjian Bongaya (1667). 
Company) makin meningkat dalam usaha masing-masing untuk menguasai sumber rempah-rempah di Kepulauan Nusantara. Kompeni mengetahui bahwa Sultan Fakhruddin pernah berlayar bersama apa yang disebut "Cella Bangkahulu" ke Lombok. "Cella Bangkahulu" itu berasal dari Bengkulen, pantai barat Sumatra, yang pada waktu itu menjadi pusat koordinasi dagang Inggris di Nusantara. Kompeni menganggap 'manuver' politik Sultan Fakhruddin itu berbahaya, yang mungkin dimaksudkan untuk mempengaruhi Bima yang telah menjadi 'sahabat' VOC agar beralih hubungan politik dan dagang dengan Inggris. Jika itu terjadi, kepentingan politik dan perdagangan VOC di Sumbawa tentu akan terganggu.

Dalam bulan April 1767, Sultan Fakhruddin yang hendak menyingkir membawa ibundanya dari Bima tiba-tiba ditangkap oleh Residen Belanda di sana. ${ }^{6}$ Waktu itu yang menjabat Gubernur Jenderal VOC adalah Petrus Albertus van der Parra. ${ }^{7}$ Belum diperoleh keterangan apakah ketika Sultan Fakhruddin ditangkap di Bima, istrinya, Siti Hapipa, juga turut ditangkap. Juga belum diperoleh keterangan apakah waktu itu Sultan Fakhruddin sudah menikah. Dengan mencermati isi Cod.Or.2241-I 25 [Klt 21/no.526] besar kemungkinan pada waktu ditangkap di Bima, Sultan Fakhruddin belum menikah dengan Siti Hapipa. Sangat mungkin Siti Hapipa bertemu dengan Sultan Fakhruddin di Colombo, dan tampaknya sebelumnya perempuan itu sudah menikah dengan pria lain yang tidak memberinya anak. Sedangkan dengan istri pertamanya yang tidak diketahui namanya, Sultan Fakhruddin memiliki seorang anak yang bernama Karaeng Sangunglo (lihat uraian di bawah). Setelah ditangkap, mula-mula Sultan Fakhruddin diasingkan ke Batavia, kemudian pada tahun itu juga dia dibuang ke Ceylon. Sementara itu, di Gowa, untuk mengisi tahta kerajaan yang kosong, diangkatlah saudara Sultan Fakhruddin, I Mallisujawa Daeng Ribboko, menjadi raja, dengan gelar Sultan Makduddin. Berkali-kali Sultan Makduddin (1767-1769) meminta kepada Belanda agar saudaranya yang dibuang ke Colombo dipulangkan ke tanah kelahirannya. Akan tetapi, permintaan itu selalu ditolak. Sebagai protes, Sultan Makduddin turun tahta tanggal 3 Januri 1767 dan kembali ke kampungnya di Barombong. ${ }^{8}$

6 Pada waktu itu yang menjadi Residen Bima adalah Jacob Bikkes Bakker (mulai menjabat tahun 1764). Tahun 1768 Bakker digantikan oleh V.F. Hight dan ia menjabat Residen Bima sampai 1771 (Chambert-Loir dan Salahuddin 1999: Lampiran VII).

$7 \quad$ Petrus Albertus van der Parra adalah Gubernur-Jenderal VOC ke-28 (1761-1775). Ia lahir di Colombo, Ceylon, pada 29September 1714 dan meninggal di Batavia pada 28 Desember 1775 ketika masih menjabat (Stapel 1941: 62-63).

$8 \quad$ Uraian ini merujuk kepada Patunru (1993: 77-78, 140). Mengenai Kerajaan Gowa pada periode yang lebih awal, lihat Matthes (1883), Erkelens (1897), Andaya (1981), Caldwell (1995), dan Cummings (2007). Sumber-sumber online mengenai Kerajaan Gowa antara lain dapat dilihat dalam: http://www.4dw.net/royalark/index.html dan http://id.wikipedia. org/wiki/ Kerajaan_Gowa (diakses 14-4-2008). 


\section{COD.OR.2241-I 25 [KLT 21/NO.526]: CATATAN KODIKOLOGIS, BAHASA, DAN TULISAN}

Surat Siti Hapipa berukuran 49 × 39,5 cm, ditulis dengan tinta warna hitam. Surat ini tidak memiliki stempel (cap) (lihat Ilustrasi 2). Bahan surat adalah kertas Eropa dengan cap kertas (watermark) Fleur-de-Lis dan countermark BUDGEN 1803. Panjang surat satu halaman dan berjumlah 32 baris. Surat ini tersimpan bersama 24 surat-surat Nusantara lainnya dalam Bagian I bundel Cod.Or.2241 ${ }^{9}$ koleksi Universiteitsbibliotheek Leiden (Wieringa 1998: 391).

Teks ditulis dengan aksara Jawi dengan bahasa Melayu yang di sanasini memperlihatkan pengaruh bahasa Bugis, seperti dapat dilihat misalnya pada penulisan kata kesukarang ('kesukaran'; baris 23, lihat c. [atatan kaki] 38). Juga ditemukan banyak kata yang mendapat tambahan huruf - $h$ di akhirnya, seperti adah [ada], dibawah [dibawa], Bagindah [Baginda], Batarah [Batara], mejah [meja], juah [jua], Gowah [Gowa], lamah [lama], dan rupah [rupa] - suatu gejala yang cukup umum ditemukan dalam naskah-naskah Nusantara (Voorhoeve 1964: 262; Chambert-Loir 1985: 25; Chambert-Loir 2004: 37; Wieringa 2003: 49; Suryadi 2007a: 196; Suryadi 2007b: 292; Suryadi akan terbit), namun cenderung menghilang dalam kitab-kitab cetak batu beraksara Jawi. ${ }^{10}$ Sebaliknya, huruf - $h$ tidak dituliskan pada sejumlah kata yang seharusnya berakhir dengan huruf itu, seperti jerni [jernih], pengasi [pengasih], bole [boleh], te [teh], ruma [rumah], dan tamba [tambah]. Beberapa kata ditulis tidak konsisten, misalnya ada / adah dan bawa / bawah. Ada juga kata-kata dengan bentuk morfologis yang cukup aneh seperti membicahrakan [maksudnya: 'membicarakan']. Huruf $g$ dan $k$ dikodifikasikan dengan huruf kaf tanpa titik, tetapi untuk $g$ kadangkadang huruf kaf diberi titik (misalnya pada kasus kata negeri dan maka yang dicontohkan di bawah).

Beberapa bagian surat ini cukup kaligrafis, misalnya kepala surat, yang menyerupai bentuk perahu, kolofon, dan baris-baris tertentu dalam tubuh surat yang dicetak tebal dengan huruf yang lebih besar (Ilustrasi 1 dan 2). Kecenderungan kaligrafis juga dapat dilihat pada penulisan beberapa huruf, seperti huruf $k$ atau $g$, misalnya pada kata negeri ( dan maka ( dan

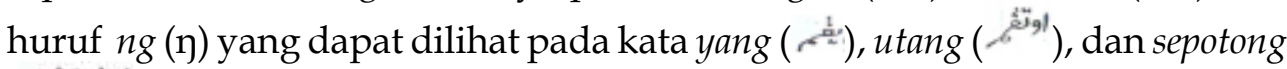
(2) Tampak bahwa bagian yang ditambahkan di atas huruf $k$ dan 'ekor' huruf $n g$ yang memutar ke bawah itu adalah semacam unsur kaligrafis paling sederhana yang terlihat dalam tulisan Jawi surat ini.

$9 \quad$ Bundel Cod.Or.2241 Universiteitsbibliotheek Leiden terdiri atas empat bagian yang seluruhnya berisi 98 pucuk surat Nusantara dari abad kedelapan belas dan sembilan belas: Bagian I (25 surat), Bagian IIa (13 surat), IIb (9 surat), dan IIc (10 surat); Bagian IIIa (8 surat) dan IIIb (22 surat); dan Bagian IV (11 surat) (Wieringa 1998: 385-409).

10 Mengenai penambahan huruf $-h$ ini, Robson (1969:3) menulis: "Does the custom of adding $-h$ represent simply a curiosity of handwriting, or is there, for example, a dialectical difference reflected here? A consideration worthy of attention is the fact that many of these words with $-h$ 'added' concern highly placed persons in some way or other - might we say that the - $h$ is intended to raise the 'tone' of the words?" Orang tidak memikirkan kemungkinan 'cengkok' yang dianggap huruf $h$ itu sebagai unsur kaligrafis yang paling sederhana dalam teks-teks beraksara Jawi yang ditulis tangan. 'Kecurigaan' ini antara lain didasarkan atas fakta bahwa fenomena ini tidak muncul dalam teks-teks Jawi cetak batu (litografi). 
Penggunaan kaligrafi dalam surat-surat Melayu lama memiliki nilai estetika dan makna simbolik tertentu (Ab Karim 2001). Jadi, bentuk kepala surat yang kaligrafis dan menyerupai bentuk perahu, seperti dipakai dalam surat ini (Ilustrasi 1), sangat mungkin memiliki estetika dan makna simbolik tertentu. Namun, belum ada pembahasan akademis yang komprehensif tentang estetika dan makna simbolik kepala surat Melayu lama. Saya berspekulasi bahwa bentuk perahu itu sangat boleh jadi merefleksikan lingkungan geografis tempat tinggal kelompok-kelompok etnis yang mendiami wilayah Nusantara yang memang dikelilingi perairan yang luas (laut dan sungai-sungai) yang sangat mempengaruhi kebudayaan dan filsafat hidup mereka (Boomgard 2007). 'Budaya air' masyarakat Nusantara itu terefleksi juga dalam bahasa dan kesusastraan mereka. Misalnya, dalam banyak pantun dan syair Melayu kata perahu - dengan variasi nama seperti pencalang, jongkong (atau jukung), bidu[a]k, sampan, dan kolek - sebagai salah satu jenis sarana transportasi yang terkait dengan air dipakai untuk menyimbolkan cinta dan jiwa kesufian (Braginsky 2007). ${ }^{11}$

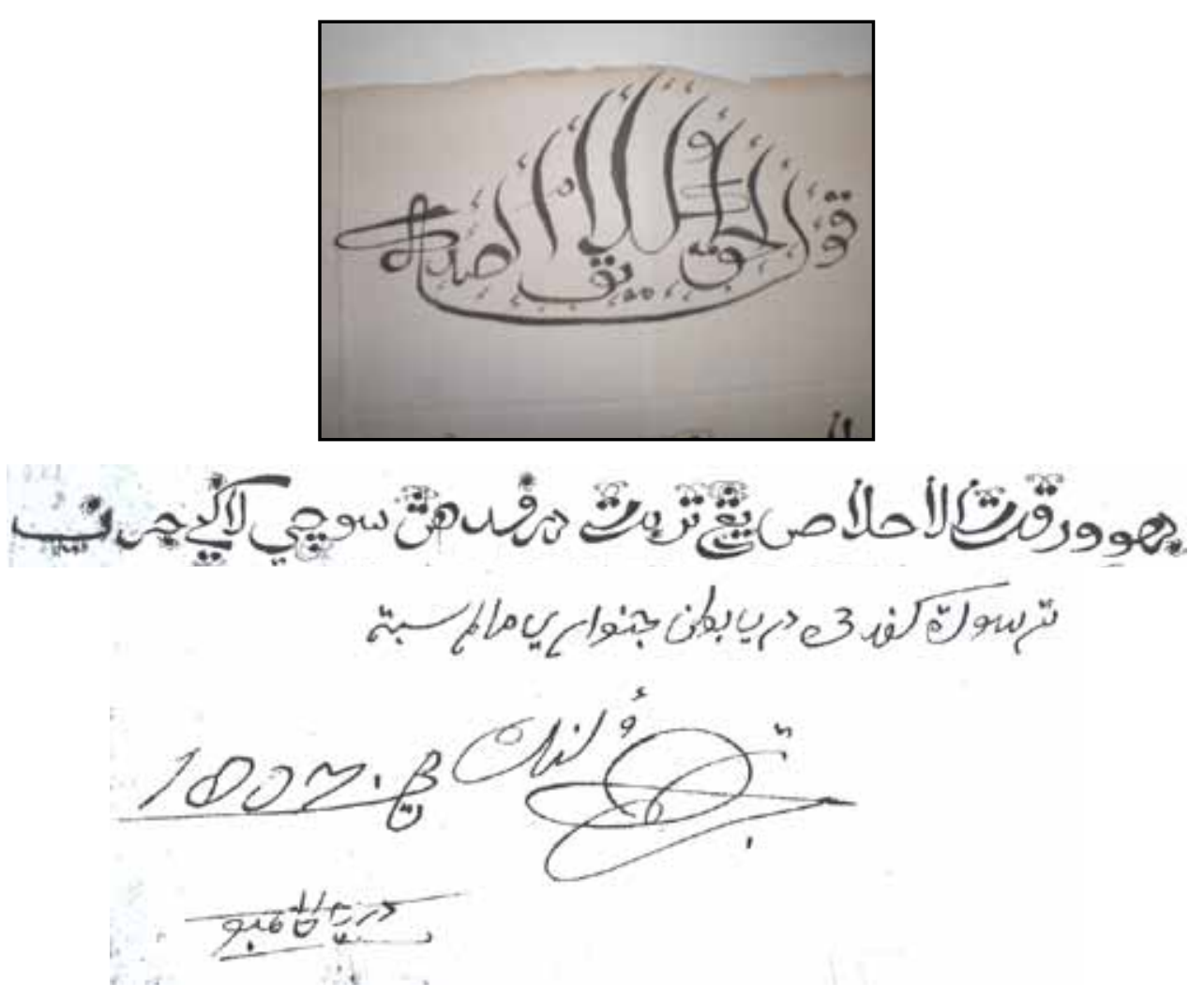

Ilustrasi 1: Unsur kaligrafis dalam Cod.Or.2241-I 25 [Klt 21/no.56]: kepala surat, baris pertama surat, dan kolofon.

11 Dalam banyak pantun Minangkabau, misalnya, kata sampan (perahu) sering dipakai untuk menyimbolkan ikatan cinta, perasaan kalah, hina, dan tersisih. Banyak pantun Minang dengan perlambangan sampan pada baris isinya dapat dilihat dalam sejumlah naskah schoolschriften berbahasa Melayu-Minangkabau yang kini tersimpan di Universiteitsbibliotheek Leiden (lihat Van Ronkel 1921). 


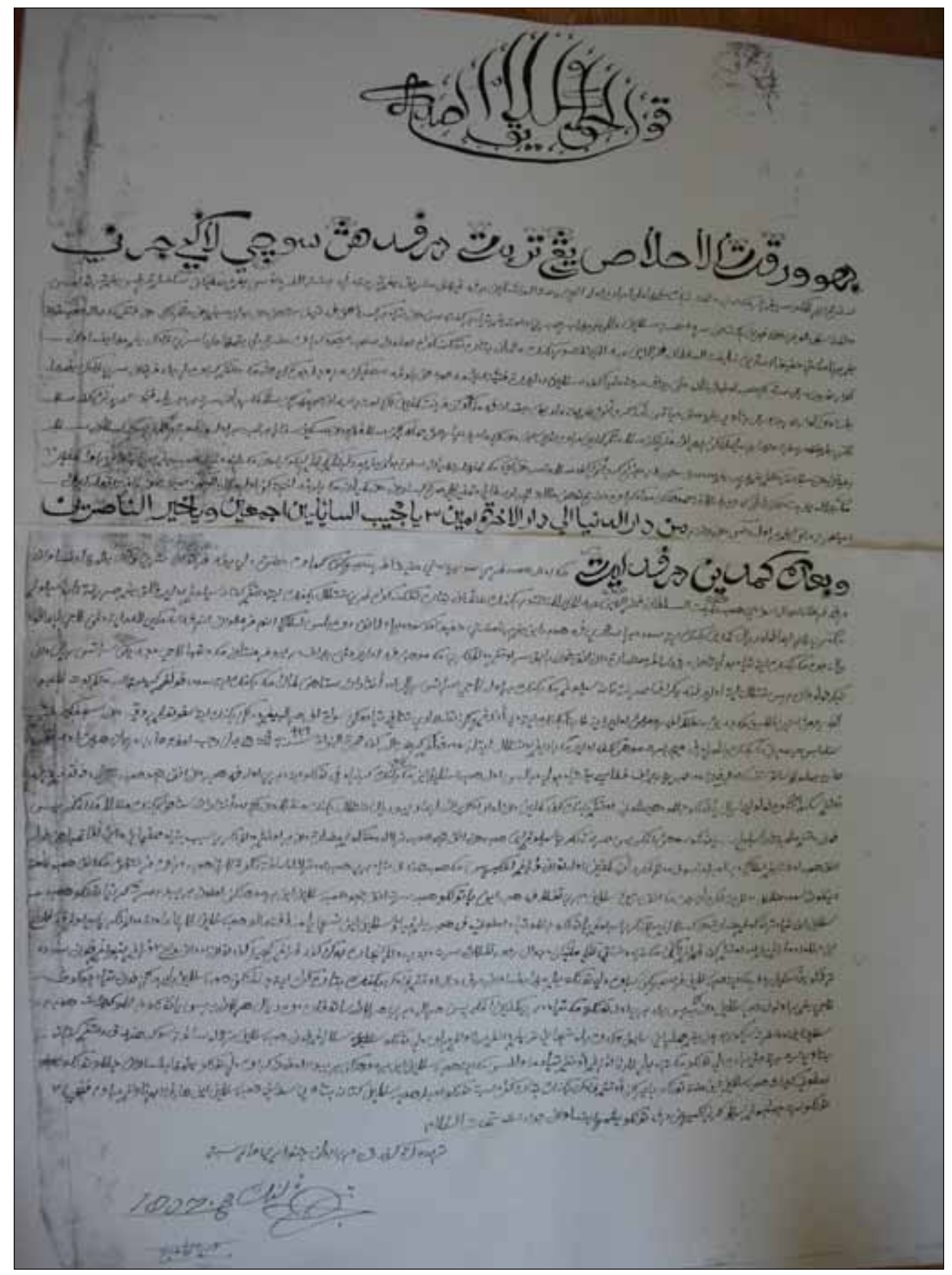

Ilustrasi 2: Surat Siti Hapipa Cod.Or.2241-I 25 [Klt 21/no.526] (koleksi Universiteitsbibliotheek Leiden).

Beberapa bagian surat dicetak tebal dengan ukuran huruf yang jauh lebih besar dari bagian surat yang lain (Ilustrasi 1 dan 2). Ada beberapa kesalahan tulis yang dicoret oleh penulisnya, dan di beberapa tempat ada kata yang 
diselipkan kemudian (ditulis agak kecil). Cukup unik bahwa kata 'Gubernur

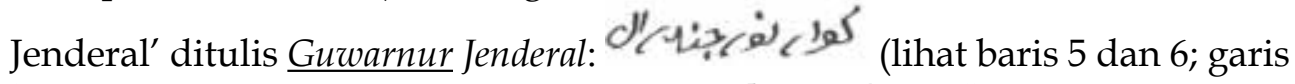
bawah oleh Suryadi). Teks Cod.Or.2241-I 25 [Klt 21/no.56] juga mengandung banyak kata dan frase bahasa Arab, seperti biasa ditemukan dalam surat-surat Melayu lama.

\section{TRANSLITER ASI SUR AT SITI HAPIPA}

Transliterasi (alih aksara) surat Siti Hapipa (Cod.Or.2241-I 25 [Klt 21/no.526], Ilustrasi 2) ini disertai dengan suntingan, tetapi diusahakan sedekat mungkin dengan surat aslinya. Misalnya, bagian yang dicetak tebal dalam surat aslinya juga dicetak tebal dalam transliterasi; kata-kata yang salah tulis dalam surat aslinya juga diturunkan dalam transliterasi yang ditandai dengan coretan (strikethrough); juga kata-kata yang disisipkan dalam surat aslinya ditulis kecil dalam transliterasi dan ditaruh dalam posisi superscript. Transliterasi dicetak dengan huruf lebih kecil untuk membedakannya dengan bagian lain dari artikel ini. Penambahan huruf $-h$ di akhir kata-kata tertentu dipertahankan dalam transliterasi, meskipun kadang-kadang diberi tanda " $<>$ " (lihat uraian di bawah) untuk lebih memperjelas artinya dalam konteks kalimat di mana kata itu berada. Sebaliknya, kekurangan huruf $-h$ atau huruf lainnya pada kata-kata tertentu ditambahkan dengan menempatkannya dalam tanda "[ ]". Ada beberapa catatan - penjelasan tambahan dan kutipan bentuk asli tulisan Jawi kata-kata tertentu (yang langsung diambil dari surat aslinya, tidak diketik ulang) - yang dimaksudkan untuk memperjelas konteks dan isi surat ini. Suku kata atau huruf yang ditaruh dalam tanda " $<>$ " dapat diabaikan ketika membaca transliterasi untuk memperjelas makna. Aspek penyuntingan lainnya adalah penambahan pungtuasi dalam transliterasi: saya menambahkan tanda baca di sana-sini yang tujuannya tiada lain untuk memperjelas isi surat. Pergantian baris ditandai dengan angka yang ditaruh di antara dua garis miring dalam transliterasi. Gunanya semata-mata untuk memudahkan merujuk teks surat ini dalam pembicaraan ini. Berikut transliterasi lengkap surat Siti Hapipa tersebut. ${ }^{12}$

\section{Qauluhu al-haqq wa kalamuhu al-sidq, ${ }^{13}$}

/1/ Bahwa warkat al-i[k]hlas ${ }^{14}$ yang terbit daripada hati ${ }^{15}$ suci lagi jerni[h] $]^{16}$

/2/ seperti air kalkausar ${ }^{17}$, yang termaktub di dalamnya nabazah Yang Maha Mulia

12 Saya mengucapkan terima kasih kepada Ian Proudfoot yang telah memberi beberapa catatan dan komentar terhadap versi awal transliterasi ini.

13 Artinya: "Perkatannya benar dan ucapannya dapat dipercaya'.

14 Bentuk Jawinya: الأ لأصى.

15 Bentuk Jawinya: هُ

16 Bentuk Jawinya:

17 Bentuk Jawinya: ' berasal dari Sungai Kalkausar yang diyakini oleh umat Islam mengalir dalam surga. 
dibawa $<\mathrm{h}>18$ oleh angin rihat al-masyikin daripada pihak masyrik, yang terbit daripada jannat al-firdaus, yang menyampaikan sekeping kertas yang tertulis /3/ dalamnya segala puji-puyan pujian bagi Tuhan Seru Semesta ${ }^{19}$ Sekalian Alam Yang Maha Besar, memberi rahmat yang tiada berkeputusan dan tiada berkesudahan pada tiap2 tahun dan bulan, siang dan malam, pagi dan petang. Maka adalah hamba Tuan

/4/ yang bernama Siti Hapipa ${ }^{20}$, istrinya Khalifat al-Sultan Fakhru al-Din Abdul Khair al-Mansur Bagindah Usman Batarah Tangkana Gowah ${ }^{21}$, empunya sembah sujud ke bawah Hadirat Duli Yang Maha Mulia Sri Paduka Yang Maha Bangsawan

/5/ Guwarnur ${ }^{22}$ Jenderal, serta lagi hamba empunya tabe dengan beberapa hormat mulia kepada sekalian Adeler ${ }^{23}$ Rat van India, mudah-mudahan barang disampaikan Aza Wajalla juah kiranya, maka datang ke bawah Duli Yang Dipertuan Sri Paduka Yang Maha

/6/ Bangsawan Guwarnur Jenderal [di] Betawi yang duduk di atas tahta kerajaannya, yang amat arif bijaksana pada melakukan perintah Kompeni, lagi amat budiman membicahrakan ${ }^{24}$ segala pekerjaan, serta berdirilah panji2 hadiratnya kepada segala

/7/ negeri yang masyhur seperti matahari melimpahkan cahayanya menerangkan segala alam Kompeni di bawah angin ini, dan lagi adil bicarahnya ${ }^{25}$ memeliharakan segala fakir dan miskin supaya bertambah2 beroleh manfaat di dalam peri sukakesukaan segala

/8/ rakyatnya dan segala anak dagang yang gharib yang adah duduk di dalam bandar daerah kerajaannya kepada segala masa dan ketika. Maka limpahlah cahayanya seperti bulan yang amat gilang-gemilang kilau-kilauan. Maka berlindunglah hamba yang adah bernaung di bawa[h] Kompeni.

/9/ Maka beberapa yang menadahkan tangan kedua $<\mathrm{h}>$ belah ke langit, memohonkan doa ke bawah hadirat Tuhan Malik al-Jabbar, supaya ditump $<\mathrm{i}>$ ahi hati kebesaran dan kem[ul]iaan, maka barang dilanjutkan oleh Malik al-Rahman sehat dan afiat apa $<\mathrm{h}>$ lah kiranya

18 Bentuk Jawinya: ‘ls. Dalam konteks ini maksudnya 'dibawa'.

19 Bentuk Jawinya: huruf kedua adalah mim, bukan ha.

20 Bentuk Jawinya: Respanya nama depan Siti lazim dipakai di kalangan wanita bangsawan di Kerajaan Gowa pada masa lampau. Ada banyak wanita dengan nama depan Siti dalam silsilah raja-raja Gowa (lihat http://www.4dw.net/royalark/index.html; diakses 15-4-2008).

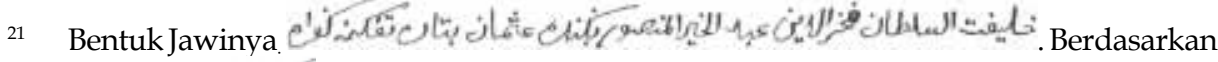

bentuk Jawinya, kata $e^{\prime \prime}$ saya transliterasikan Gowah, bukan Goah, meskipun kedua-duanya ditemukan dalam literatur sejarah -- ditulis Gowa atau Goa. Seperti telah disebutkan di atas, huruf $-h$ tambahan di akhir kata yang menurut Chambert-Loir (2004: 37) tidak mempunyai nilai fonetik tetap ditampakkan dalam transliterasi ini.

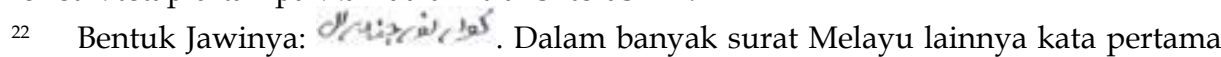
biasanya ditulis Gurnadur atau, dalam beberapa kasus, Gurandur, yang menurut saya keliru.

23 Bentuk Jawinya: $\frac{1}{1}$ yang juga bisa dibaca adelir, berasal dari kata Belanda edeleer, yaitu gelar anggota Dewan Hindia-Belanda (Wojowasito 2003: 171).

24 Bentuk Jawinya: ${ }^{2}{ }_{0}$; ; jelas maksudnya 'membicarakan'.

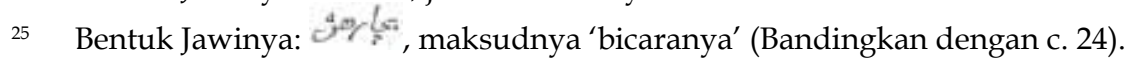


/10/ usia umur zamannya yang beroleh rahman dan rahim min dar al-dunya ila dar al-akhirat, amin3 ya mujib al-sailin ajmain wa ya khair al-nasirin. ${ }^{26}$

/11/ Wabakdahu kemudian daripada itu maka adalah hamba Permaisuri Siti Hapipa persembahkan ke bawah Hadirat Duli Yang Dipertuan Sri Paduka Yang Maha Bangsawan,

/12/ daripada peri hal ihwal suami hamba [K]halifat ${ }^{27}$ al-Sultan Fakhru al-Din Abdul Khair al-Mansur Bagindah Usman Batarah Tangkana Gowah peri tatkala Bagindah itu datang ke Tanah Selong ${ }^{28}$, Adeler Falk ${ }^{29}$ yang memerintah Tanah Selong, /13/ maka diberi gaji lima pulu[h] riyal. Kemudian Bagindah itu sudah beristri pada hamba ini yang bernama Siti Hapipa, maka sudah beroleh anak duah belas: laki-laki enam, perempuan enam, pada sedemikian lamah itu dengan gaji lima puluh /14/ riyal juah. Maka Bagindah itu tiada boleh tahan daripada sangat mudarat dan anak pun banyak berutang ${ }^{30}$ di dalam negeri, maka mohon pada Adeler dengan beberapa ribu permintaan, maka ditamba[h] gaji, dijadikan seratus riyal dan

/15/ tiga puluh parah ${ }^{31}$ beras. Tatkala itu Adeler Van de Graaf ${ }^{32}$ memerintah Tanah Selong, maka Bagindah beroleh gaji seratus riyal. Adah antaranya setahun lamanya maka Bagindah itu sudah pulang ke Rahmatullah di dalam kota Kolombo /16/ kepada ruma[h]nya Adeler Enggelbek ${ }^{33}$. Maka jadinya meninggal kepada

26 Arti kalimat Arab yang dihitamkan itu sebagai berikut: “[...] dari dunia sampai akhirat, amin, amin, amin [semoga Engkau mengabulkan] wahai Zat yang Maha Mengabulkan orang-orang yang memohon, segalanya, wahai Zat sebaik-baik Penolong."

27 Bentuk Jawinya:

28 Bentuk Jawinya: Selung) yang mengingatkan kita pada salah satu surat kabar Melayu beraksara Jawi yang terbit di Ceylon pada akhir abad kesembilan belas, Wajah Selong (1895-1898) yang dikelola oleh Baba Ounus Saldin (Hussainmiya 1991: 110; Adam 1992: 110, [130], Gambar 16). Dalam sastra Melayu lama dan juga sastra lisannya, nama Ceylon sering ditulis atau diucapkan Sailan atau Sahilan.

29 Bentuk Jawinya: $1 / 2$. Yong dimaksud adalah Iman Willem Falck, Gubernur VOC ke-31 untuk Ceylon yang berkuasa tahun 1765-1785 (Schrikker 2007: 253).

30 Bentuk Jawinya: Tampaknya huruf $b a(ب)$ di awal kata ini lupa diberi titik di bawah. Kesimpulan ini didasarkan atas perbandingan dengan tulisan Jawi untuk kata yang sama yang terdapat pada baris ke-20.

31 Bentuk Jawinya: (juga pada baris 26), dari bahasa Jawa, yang menurut Wibisono dan Robson (2002: 542) berarti: "variety of basket used for measuring a quantity of fruits etc". Sedangkan menurut Gericke dan Roorda (1901: II, 219) kata itu berarti: "een zekere groote maat, een mand of ton voor drooge en nette waren". Kata parah merujuk kepada kata centhak yang berarti "een maat (tot 100 kati's toe) voor drooge waren, bv. Koffie en zout, vlg. parah" (Gericke dan Roorda 1901: I, 250) dan takeran yang berarti "inhoudsmaat" (Gericke dan Roorda 1901: 640). Dalam kamus klasik lainnya ukuran parah disebutkan sama dengan 10 gantang atau \pm 10 gallons (Winstedt 1963: 258).

32 Bentuk Jawinya: 1 sang dimaksud adalah Willem Jacob van der Graaff, Gubernur VOC untuk Ceylon (1785-1794), suksesor Iman Willem Falck. Adalah Van der Graaff yang menggagas pembukaan besar-besaran perkebunan kulit manis (cinnamon) di Ceylon yang kemudian memberi banyak keuntungan kepada Belanda (Schrikker 2007).

33 Bentuk Jawinya: dalam beberapa kepustakaan klasik ditulis "L.G. van Anglebeck" (lihat misalnya An officer [H.S.] 1876: I, 342) atau "M. Van Angelbeck" (lihat misalnya Percival 1803: 105) - yaitu ayah mertua Gubernur Van der Graaff (lihat c. 32), yang kemudian menjadi suksesornya mulai Juli 1794. Masa jabatannya singkat karena pada tahun 1796 Belanda yang diduduki Prancis dalam Perang Eropa terpaksa menyerahkan Ceylon kepada Inggris atas perintah Raja Belanda 
rumahnya Adeler itu karena Bagindah itu diundang makan tengah hari tetapi tiada makan suatu apa $<\mathrm{h}>$, hanyalah yang dimakan Bagindah itu sepotong roti dan secangkir te[h] ${ }^{34}$.

/17/ Setelah [h]abis minum te[h] maka Bagindah bangun $<$ g $>$ lah daripada meja $<\mathrm{h}>$ serta mohon kepada Adeler, maka baring2, tatkala itulah sudah pulang ke Rahmatullah kepada hijrat al-nubuwat sanat $921^{35}$ tahun Ha bulan Rajab empat hari dari bulan, harinya Ahad tengah

/18/ hari jam pukul satu setengah. ${ }^{36}$ Maka Adeler pun sudah memberi beberapa pengasi[h] yang tiada bole[h] dibalas oleh hamba sekalian ini. Maka gaji Bagindah kurnia daripada Tuanku itu diberi oleh pada hamba dan anak cucu hamba tetapi dipotong daripada

/19/ utang segenap2 bulan duahpulu[h] lima riyal. Ya Tuanku, jikalau dihimpuni utang Bagindah kepada Kompeni dan di luar ada kiranya lima ribu riyal tatkala Bagindah meninggal, dan lagi adah antaranya setahun Bagindah meninggal maka Inggiris /20/ pun datang mengambil Tanah Selong. Ya Tuanku, sudahnya Inggiris memerintah Negeri Selong ini, hamba dan anak cucu hamba terlalu menanggung mudarat dan berutang di dalam negeri sebab tiada mempunyai daya upa[ya]. Tambahan pula /21/ anak hamba empat yang laki-laki diambil masuk di dalam pekerjaan Kompeni oleh Tuan orang Inggiris. Maka hamba hendak tiada beri, hamba adah terlalu sangat takut karena hamba di bawah perintahnya. Maka anak hamba keempat

/22/ itu pun sudah meninggal di dalam itu pekerjaan juah. Maka anak bininya sekalian diberi tinggal pada hamba ini. Ya Tuanku, hamba serta anak cucu hamba sekalian ini bermohonkan ampun beribu2 serta kurnia Tuanku, hamba

/23/ sekalian ini tiada tertanggung mudarat dan kesukarang ${ }^{37}$ di dalam Negeri Selong. Ya Tuanku, jikalau tiada diampuni pada hamba yang piatu sekalian ini niscaya mendapat malu hamba sekalian karena adat di dalam Negeri Selong pada sekarang

/24/ ini jikalau adah orang yang adah utang kepada orang lain maka tiada dinanti lagi melainkan dijual rumah tangganya serta dibubuh dalam kenjarah ${ }^{38}$, bukan kepada orang kecil, kepada tuan2 dan raja2 orang te[r]buang pun sudah

/25/ terlaku yang demikian rupa $<\mathrm{h}>$. Maka itu hamba sekalian persembahkan ke bawah Duli Tuan Yang Maha Bangsawan daripada hal utang Paduka Bagindah

Willem 1 yang menyingkir ke Kew di Inggris (Schrikker 2007: 118, 253). Anak Johan Gerard van Angelbeek, Christiaan van Angelbeek, salah seorang saudara sepupu dan loyalis Gubernur Van der Graaff, diangkat menjadi dessava (kepala administratif propinsi) di Matara pada 1786 (Schrikker 2007: 70). Dengan mempertimbangkan konteks historis ini, maka tampaknya yang dimaksud oleh Siti Hapipa dalam suratnya adalah sang bapak (Johan Gerard van Angelbeek), bukan anaknya (Christiaan van Angelbeek).

34 Bentuk Jawinya: ${ }^{3 / 3}$ (juga pada baris 17), yang penulisannya kemungkinan dipengaruhi oleh cara pelafalan kata ini dalam bahasa Inggris.

35 Tertulis: ${ }^{411}$, yang harus dibaca terbalik: 12[0]9 H. Sistem penulisan terbalik seperti ini rupanya cukup sering digunakan dalam surat-surat Melayu lama (lihat Gallop 2002: I, 174176).

36 Berdasarkan keterangan ini, berarti Sultan Fakhruddin mangkat pada hari Minggu, pukul 13:30, 4 Rajab 1209 H (25 Januari 1795) di rumah dinas Gubernur Johan Gerard van Angelbeek di Colombo (lihat Ilustrasi 5).

37 Bentuk Jawinya: 24 , maksudnya kesukaran. Ini biasa terjadi kalau orang berbahasa ibu Bugis melafalkan kata Melayu yang berakhir dengan bunyi $n$, dan melafalkan sebaliknya untuk kata-kata Melayu yang berakhir dengan bunyi ng (lihat c. 39).

38 Bentuk Jawinya: mungkin maksudnya penjara. 
Batarah Gowah itu. Jangankan hamba sekalian bayar, [untuk] makanpun tiada cukup

/26/ gaji yang beroleh pada hamba sekalian, dan lagi besar sayang [yang] diberi oleh Tuanku, maka tiada diberi Kompeni Inggiris, hanyalah diberi harganya satu parah dua $<$ h $>$ riyal harganya beras. Ya Tuanku, jikalau kiranya hamba

/27/ sekalian ini adah seperti seekor burun[g] $]^{39}$ yang mempunyai sayap $\mathrm{h}$ kedua belah, niscaya terbang datang bernaung di bawah Duli Tuanku. sekayal Sekarangpun hamba sekalian terlalu sangat suka hendak datang ke Tanah

/28/ Betawi serta bernaung di bawah Duli Tuanku, maka tiada boleh karena orang utang tiada mau lepas. Maka itu hamba sekalian ini bermohonkan beribu2 ampun ke bawah Duli Tuanku Yang Maha Bangsawan, jikalau Tuanku ampu

/29/ ampuni kiranya hamba sekalian ini minta Tuanku bayar akan utang Padukah Bagindah Batarah Gowah serta Tuanku ambil hamba sekalian ke Tanah Betawi supaya hamba sekalian ini harap2 bernaung di bawah panji2

/30/ Tuanku serta junjung segala kurnia kasihan daripada Tuanku Yang Maha Bangsawan jua adanya. Tammat al-kalam.

Tersurat kepada 3 dari bulan Januari malam Sabtu hijrat Ol[1]andah ${ }^{40}$ tahun 1807 dari Kolombo

\section{KOTA PEMBUANGAN: COLOMBO AKHIR ABAD KEDELAPAN BELAS DAN AWAL ABAD KESEMBILAN BELAS}

Konteks historis surat Siti Hapipa adalah Ceylon, khususnya Colombo, pada seperempat terakhir abad kedelapan belas dan dekade pertama abad kesembilan belas. Pada masa itu sebenarnya VOC masih jaya sebelum kemudian mengalami kebangkrutan dengan cepat sehingga terpaksa dibubarkan pada 31 Desember 1799. VOC pertama kali masuk ke Ceylon pada tahun 1638 atas 'undangan' Raja Kandy, Rajasinha II (1635-1687), yang berusaha mengusir Portugis dari negerinya. Armada dagang Portugis yang juga membawa misi pengkristenan pertama kali masuk ke Ceylon pada tahun 1505 di bawah pimpinan Almeyda (Percival 1803: 5). Kedatangan Portugis di Ceylon mengakhiri dominasi jaringan pedagang Islam dari Arab dan Persia di kawasan itu.

Baru pada tahun 1658 VOC benar-benar berhasil mendepak Portugis dari Ceylon. Penguasaan VOC atas Ceylon, seperti telah dicatat dalam sejarah, bertahan selama hampir satu setengah abad, telah banyak mengubah aspek politik, ekonomi, dan sosial masyarakat pulau itu (Schrikker 2007: 13-29). Berbeda dengan Portugis, dan kemudian Inggris, VOC mencoba bersahabat dengan Kerajaan Kandy, yang dikuasai bangsawan Singhala, yang sangat berpengaruh di pedalaman, walaupun beberapa kali terjadi konflik. Misalnya, pada tahun 1604, utusan VOC, Joris van Spilbergen bertemu dengan Raja Kandy untuk menjalin persahabatan. Pada tanggal 23 dan 31 Maret 1785 Duta VOC Cornelis de Cock diterima oleh Raja Kandy, Rajadhi Rajasinha (1782-1798) (Zandvliet 2002: 27-29, 254-262).

39 Bentuk Jawinya: ¿r?, maksudnya burung.

40 Seperti dapat dilihat pada Ilustrasi 1, ada huruf hamzah (s) di atas huruf waw (و) tapi menurut saya huruf hamzah itu harus dibaca mendahului huruf waw sehingga kata itu dapat dibaca $\mathrm{Ol}[1] \mathrm{anda}<\mathrm{h}>$, bukan Wolanda $<\mathrm{h}>$. 


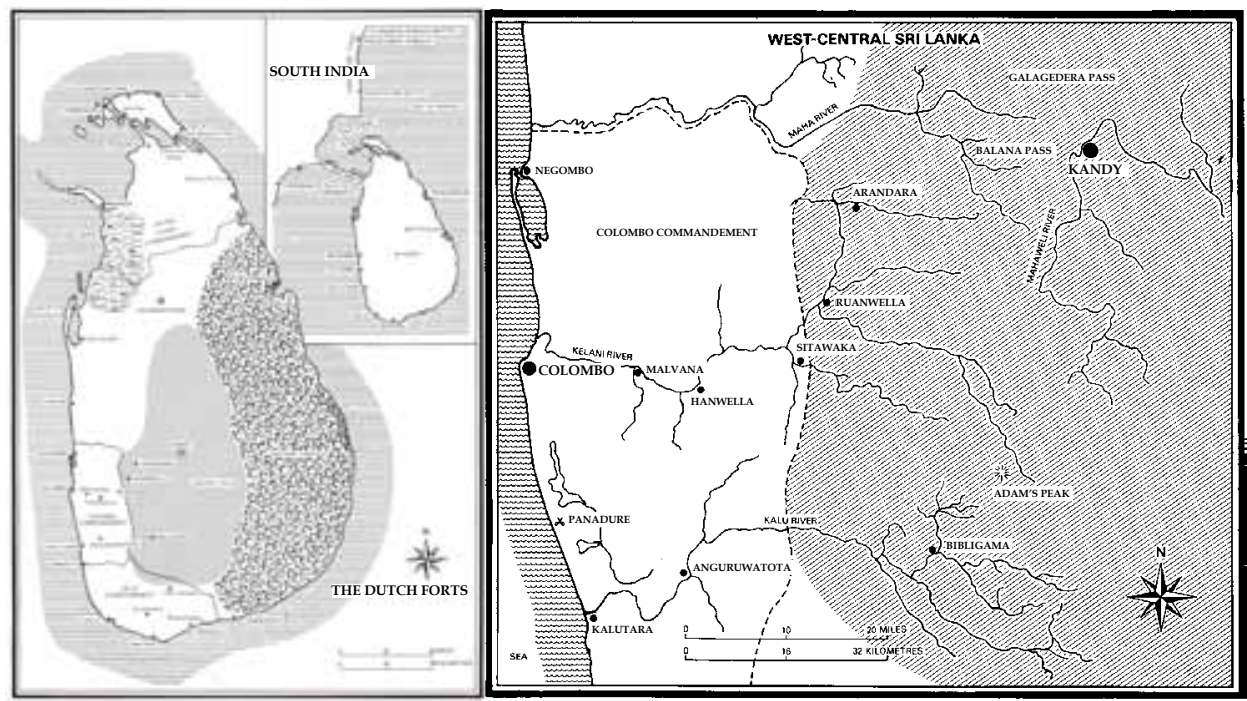

Ilustrasi 3: Pulau Ceylon [Sri Lanka] dengan ibukota Colombo yang terletak di pantai barat (Nelson 1984: 12, depan sampul dalam).

Peralihan kekuasaan kolonial dari Portugis kepada Belanda (VOC) telah ikut mengubah wajah Kota Colombo. Seperti Portugis, VOC menjadikan Colombo sebagai pusat administrasi kolonialnya di Ceylon.

It was seat of the Governor, who ranked as one of the major [VOC] officials of the East. He was assisted by a Council of eight. To that number were added the Lieutenant-Governors of Galle and Jaffna when they were in Colombo. On the Council they ranked next to the Governor. (Nelson 1984: 17).

Penataan Kota Colombo pun disesuaikan dengan selera arsitektur Belanda. Model "single unit" yang dibangun Portugis dengan kawasan utama Fort dan Pettah diubah oleh VOC. Pelabuhan Colombo diperluas dan di sekelilingnya dibangun benteng perlindungan yang lebih kuat. Tiga gerbang besar menghubungkannya ke daratan melewati kanal yang merupakan bagian dari Danau Beira. Bagian-bagian benteng diberi nama menurut nama kota-kota di Belanda: Leyden, Delft, Amsterdam, Harlem, dan lain-lain (Percival 1803: 98; Nelson 1984: 19; Ilustrasi 4).

Pada akhir tahun 1800-an, Kota Colombo yang terletak di pantai barat Pulau Ceylon (Ilustrasi 3) sudah menjadi salah satu kota pelabuhan yang penting dan strategis di kawasan Asia Selatan. Pelabuhannya menjadi tempat transit kapal-kapal dari arah barat ke timur atau sebaliknya. Kapulaga (cardamom), kayu manis (cinnamon), dan lada (pepper) adalah tiga hasil bumi penting yang diekspor dari Ceylon yang memberi banyak keuntungan kepada Belanda, kemudian Inggris, karena kedua jenis rempah itu sangat laris di Eropa (Van den Belt 2008: 58, 66-700). Arak dibuat di daerah-daerah sekitarnya dan dipasarkan secara regional. 


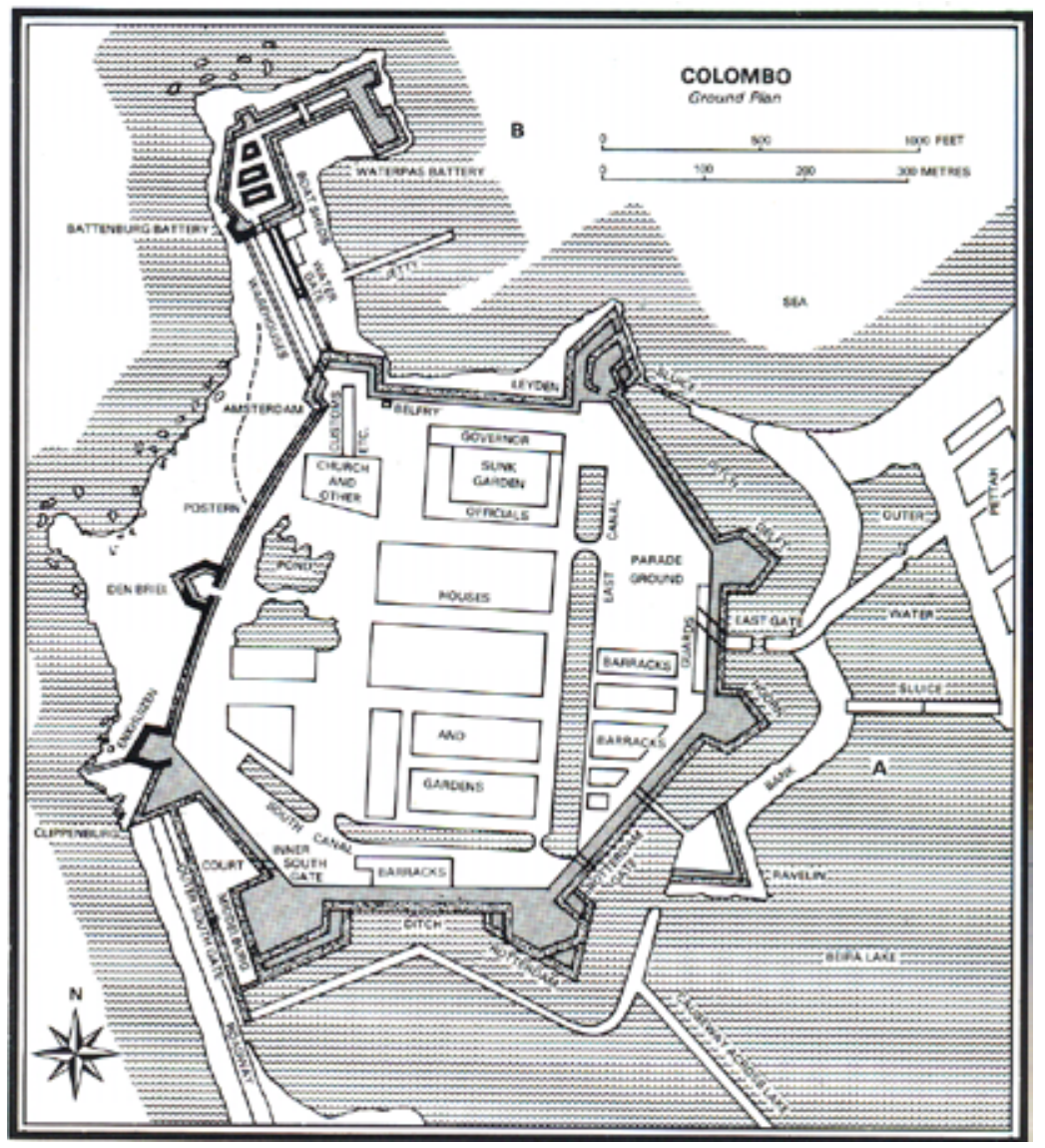

Ilustrasi 4: Pusat kota Colombo yang dikelilingi benteng pada akhir abad kedelapan belas (Nelson 1984: 19).

Karya Robert Percival ESQ yang sering dirujuk di sini berisi gambaran yang menarik tentang Ceylon, khususnya kehidupan di Colombo, pada awal abad kesembilan belas.

Every year, in general towards February, a Portuguese or Chinese ship arrives from Macao with teas, sugar, candied, sweetmeats, hams, silks, velvets, nankeens, umbrellas, strawhats, all kinds of china-ware and toys. These articles meet with a very speedy sales; and as they are generally paid in hard-money, they occasion a great deal of gold and silver to be carried out of the island. [...] The Dutch exacted a duty of five per cent on all these exports and imports, which is still continued by our Government. (Percival 1803: 117).

Percival adalah seorang pejabat teras militer kolonial Inggris yang ditugaskan di Ceylon setelah pulau itu diambil alih oleh Inggris. Buku Percival menggambarkan perkembangan Kota Colombo pada awal abad kesembilan belas. Pada masa itu, Colombo sudah menjadi kota yang cukup sibuk. 
[T] he shops, bazaars, and stalls placed all along the streets, are replenished with various articles of merchandise, peculiarity in use among the natives of India; and the town, during the whole day, swarms with people of all descriptions. In the next street, next the sea, is an excellent fish market [...]. (Percival 1803: 112).

Kota Colombo didatangi oleh banyak imigran regional dan para pembantu dari daratan India dan juga dari Hindia-Belanda. Percival juga menceritakan masyarakat Columbo - demikian ia menulisnya - yang multirasial.

Columbo taken all together is, for its size, one of the most populous places in India. There is no part of the world where so many different languages are spoken, or which contains such a mixture of nations, manners, and religions. Besides European, and Cinglese, the proper natives of the island, you meet scattered all over the town almost every race of Asiatics: Moors of every class, Malabars, Travancorians, Malays, Hindoos, Gentoos, Chinese, Persians, Arabians, Turks, Maldivans, Javians, and natives of all the Asiatics isles; Persees, or worshippers of fire, who would sooner have their houses burnt and themselves perish in the flames, than employ any means to extinguish it. There are also a number of Africans, Cafrees, Buganese a mixed race of African and Asiatics; besides the half-casts, people of colour, and other races which proceed from a mixture of the original ones. Each of these different classes of people has its own manners, customs, and language. (Percival 1803: 115).

Demikianlah gambaran umum Kota Colombo pada akhir abad kedelapan belas tempat Sultan Fakhruddin dan keluarga besarnya dibuang. Dalam pengelompokan ras dan suku bangsa di Ceylon pada waktu itu, mereka dikategorikan sebagai orang Melayu (Percival 1803: 146-166). Menurut Hussainmiya (1987: 41), Belanda mengelompokkan orang Melayu di Ceylon menjadi dua: kelompok pertama, yaitu eksil politik dan bangsawan yang dibuang oleh Batavia. Mereka adalah para raja, pangeran, ratu, dan kaum aristokrat dari berbagai daerah di Nusantara. Mereka tinggal dengan keluarga mereka di Ceylon, terutama di Colombo. Keluarga Sultan Fakhruddin adalah salah satu di antaranya. Kelompok lainnya adalah orang-orang Melayu yang dibawa Belanda ke Ceylon untuk dipekerjakan dalam berbagai bidang, khususnya di bidang ketentaraan. Namun, kedatangan bangsa Melayu di Ceylon sudah terjadi jauh sebelum orang Eropa datang ke pulau itu. Berdasarkan data-data linguistik, diperkirakan kontak antara orang Melayu dan penduduk Ceylon sudah mulai sejak abad ketiga belas (Hussein 2007: 408). ${ }^{41}$

\section{ANALISIS ISI SUR AT SITI HAPIPA}

Sebuah sumber yang mendeskripsikan dinasti raja-raja Gowa menyebutkan riwayat hidup Sultan Fakhruddin secara singkat dan juga nama istrinya yang menulis surat yang dibahas ini.

$41 \quad$ Menurut Nuhman (2007: 17), secara tradisional Muslim Sri Lanka terbagi atas lima kelompok etnis yang berbeda: "Ceylon/Sri Lankan Moors, Coast/Indian Moors, Malays, Borahs, Memons". Namun, secara umum mereka disebut “Ceylon Moors” atau "Sri Lankan Moors." 
[...] 1753 - 1767 H.H. Karaeng Batara Gowa II Amas Madina Patti Mathari Sultan Usman Fakhr ud-din [Tumamenanga-ri Silung], Sultan of Gowa. b. [orn] $9^{\text {th }}$ November 1749, elder son of H.H I-Mappaba'basa Paduka Sri Sultan 'Abdu'1 Kudus ibni al-Marhum Sultan Safi ud-din, Sultan of Gowa, by his wife, I-Taju Karaeng Balasari, educ.[ation] privately. Succeeded on the death of his father, $21^{1 \mathrm{tt}}$ December 1753 . Assumed the name of Karaeng Batara Gowa Amas Madina, June 1758. Deposed in favour of his younger brother, $14^{\text {th }}$ April 1767. Fled to Bima, captured and exiled to Batavia and then to Ceylon. m.[arried] Siti Habiba. He d.[ied] at Colombo, Ceylon, 1795 [...]. ${ }^{42}$

Jadi, menurut Buyers, istri Sultan Fakhruddin bernama Siti Habiba, sedangkan wanita itu menyebutkan namanya sendiri Siti Hapipa dalam suratnya [ ${ }^{l} \operatorname{lis}^{2}>$ ] Boleh jadi perbedaan ini disebabkan Buyers hanya merujuk catatan-catatan orang Belanda saja yang sering keliru menulis nama orang pribumi. ${ }^{43}$

Cod.Or.2241-I 25 [Klt 21/no.526] hanya menginformasikan kepada kita bahwa Siti Hapipa adalah istri Sultan Fakhruddin. Surat itu tidak memberi keterangan lain mengenai asal-usul wanita ini. Namun, menilik namanya, hampir pasti Siti Hapipa adalah salah seorang wanita bangsawan Gowa (lihat c. 20). Namun kurang jelas di mana wanita ini menikah dengan Sultan Fakhruddin. Kecil kemungkinan bahwa pasangan ini sudah menikah waktu berada di Bima sebelum ditangkap oleh VOC. Uraian Buyers di atas juga tidak memberikan rincian mengenai hal ini. Pernyataan Siti Hapipa dalam baris 13 suratnya (lihat transkripsi) memberi kesan bahwa ia menikah dengan Sultan Fakhruddin di Colombo. Demikian juga pernyataan dalam baris 14 suratnya, berkesan bahwa pasangan Siti Hapipa-Sultan Fakhruddin menikah di Colombo dan semua anak mereka lahir di sana.

Siti Hapipa mengatakan bahwa dari perkawinannya dengan Sultan Fakhruddin ia "beroleh anak dua $<\mathrm{h}>$ belas: laki-laki enam, perempuan enam, [...]" (b.[baris] 13) dan dari anak-anaknya yang sudah menikah di Ceylon Sultan Fakhruddin dan Siti Hapipa memperoleh beberapa orang cucu (b. 22). Sementara itu, menurut Buyers, anak Sultan Fakhruddin seluruhnya berjumlah sebelas orang: tujuh laki-laki dan empat perempuan, yaitu:

- 1) Karaeng Yusuf.

- 2) Karaeng Sangunglo. Escaped from the Dutch and entered the service of the King of Kandy, ca. 1800. He was $k$. in battle with the British, during the First Anglo-Kandyan War, 1803.

- 3) Capt ain Karaeng 'Abdu'llah. Capt. Malay Regt. British Army in Ceylon. He was $k$. during the Poligar Wars, in South India, 1800.

- 4) Captain Karaeng Muhammad Nur ud-din. Capt. Malay Regt. British Army in Ceylon, served in the First Anglo-Kandyan War. He was $k$. on the orders

${ }_{42}$ Dikutip dari http://www.4dw.net/royalark/Indonesia/gowa6.htm dengan copyright atas nama Christopher Buyers (diakses 15-4-2008), selanjutnya akan disebut: Buyers. Menurut Buyers, Sultan Fakhruddin lahir pada 9 November 1749. Sementara itu, menurut Patunru (1993), Sultan Fakhruddin lahir pada tahun 1747.

43 "The only guides the European [scholars and bureaucrats] of Malay had were his own ears, unconsciously adapted to English or Dutch phonology, his own English or Dutch spelling conventions, and his possible knowledge of Malay written in Arabic script" (Vikør 1988: 12). 
of the Kandyan King, after enduring three weeks of torture while a prisoner, 1803 (his body thrown to wild boars in the jungle).

- 5) Karaeng Segeri Zainal Abidin.

- 6) Karaeng Sapanang Yunusu.

- 7) Captain Karaeng Saif ud-din. Capt. Malay Regt. British Army in Ceylon, served in the First Anglo-Kandyan War. He was $k$. on the orders of the Kandyan King, after enduring three weeks of torture while a prisoner, 1803 (his body thrown to wild boars in the jungle).

- 1) Siti Awang. m. Pangeran Adipati Amangkurat, of Java.

- 2) Ratna Villis [Wilis?; Suryadi].

- 3) Ratna Wangsa.

- 4) Ratu Siti Habiba. $b$. in Ceylon, after 1768. She $d$. after $1813 .^{44}$

Dengan demikian, terdapat perbedaan antara catatan Buyers dan pengakuan Siti Hapipa sendiri. Dalam surat Siti Hapipa: ada 'kelebihan' satu orang anak lakiSultan Fakhruddin dalam daftar yang dibuat Buyers. Agaknya Siti Hapipa dalam suratnya hanya menghitung jumlah anak kandungnya saja, yaitu dua belas orang; anak tirinya, Karaeng Sangunglo tidak disebut.

Dari uraian Buyers yang dikutip di atas, diketahui pula bahwa salah seorang anak perempuan Sultan Fakhruddin, Siti Awang, menikah dengan

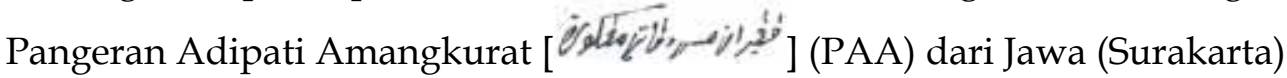
yang juga dibuang Belanda ke Ceylon. Rupanya di tanah pembuangan seperti Ceylon, terjadi perkawinan antara sesama keluarga raja atau pemimpin lokal yang dibuang Belanda. Ada kemungkinan perkawinan itu didorong oleh rasa senasib sepenanggungan, tetapi faktor kelas sosial kemungkinan juga turut menentukan.

Seperti halnya Siti Hapipa, PAA juga mengirim sepucuk surat kepada Gubernur Jenderal Hindia-Belanda di Batavia, yaitu Cod.Or.2241-I 23 [Klt 22/no.250) (Wieringa 1998: 391; lihat c. 4). Surat itu juga ditulis di Colombo, bertarikh 25 Desember 1806. PAA menulis bahwa ia "suda[h] beristri" [yang dimaksud mungkin Siti Awang; Suryadi] dan "beroleh anak lima" (b. 17). PAA ${ }^{45}$ mengaku bahwa keluarganya yang menjadi eksil di Ceylon cukup besar jumlahnya: "jikalau dihimpuni ada kiranya dua puluh orang" (b. 20). Termasuk di dalamnya anggota keluarga dari saudara PAA yang bernama "Baginda Sunan Kuning Amangkurat" [éd

$44 \quad$ Buyers (di dalam kutipan) sebagaimana aslinya.

45 Seperti halnya keluarga Sultan Fakhruddin, PAA dan saudara-saudaranya juga menerima gaji bulanan dari pemerintah kolonial Inggris di Ceylon. Ia menulis: "Maka adalah Kompeni Inggiris memberi kurnia [...] kepada hamba keempat bersaudarah segenap2 bulan riyal empat puluh tuju[h] dan beras lima puluh parah [...]" (Cod.Or.2241-I 23 [Klt 22/no.250]: b. 14). Namun, PAA tetap ingin kembali ke Hindia-Belanda karena ia dan saudara-saudaranya "terlalu mudarat" dan "tiada boleh tertanggung lagi" dan "tiada tertahani lagi di dalam Negeri Selong [Ceylon] melainkan harapkan ampun" dari Gubernur Jenderal Hindia-Belanda di Batavia dan minta dipulangkan ke Jawa (Cod.Or.2241-I 23 [Klt 22/no.250]: b. 16-17).

46 Kemungkinan besar orang ini adalah anggota keluarga Mas Garendi, anak Pangeran Tipasana, keturunan langsung Sunan Amangkurat III (berkuasa 1703-1708) (Carey 2007: 372). Baginda Sunan Kuning Amangkurat dan familinya berasal dari keturunan penguasa 
saudara kandung PAA sendiri (1 laki-laki; 2 perempuan), yaitu: Raden Mas Hamza[h] [ Berenti [ [ن-

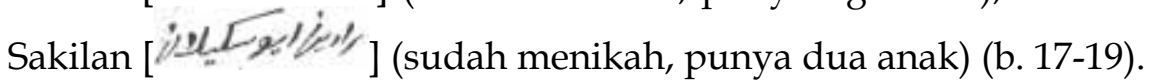

Isi surat Siti Hapipa juga memberi kesan bahwa ia cukup cakap berhitung dan mengingat tahun-tahun yang penting dalam perjalanan hidup keluarganya di Ceylon. Ia juga cukup cermat mencatat tarikh peristiwa-peristiwa penting yang menyangkut kehidupan suaminya dan keluarganya di Ceylon, yang tentu saja sangat bermanfaat bagi studi sejarah Gowa.

Baris 12 surat Siti Hapipa menjelaskan bahwa ketika Sultan Fakhruddin sampai di Colombo, yang menjadi Gubernur VOC di Ceylon adalah Iman Willem Falck (1765-1785; gubernur ke-31) (lihat c. 29). Berarti waktu itu Sultan Fakhruddin baru berumur 18 tahun (jika ia lahir tahun 1749, mengikuti keterangan Buyers). Sultan Fakhruddin sampai di Colombo pada tahun kedua masa jabatan Gubernur Falck (1767). Pemerintah VOC di Ceylon memberinya gaji bulanan - begitu disebut dalam surat - sebesar 50 riyal. Beberapa tahun lamanya gaji itu tidak dinaikkan oleh pemerintah, sedangkan jumlah keluarga Sultan Fakhruddin bertambah dengan kelahiran anak-anaknya, yang kemudian diikuti dengan kelahiran cucu-cucunya. Dengan gaji itu Sultan Fakhruddin "tiada boleh tahan daripada sangat mudarat" dan dia serta anak-anaknya terpaksa berutang ke sana-sini agar tetap bertahan hidup di Colombo (b. 14). Oleh karena itu, Sultan Fakhruddin minta tambahan gaji kepada Gubernur Falck. Akhirnya gaji bulanannya dinaikkan menjadi 100 riyal dengan tambahan "tiga puluh parah" beras, yang diterima oleh keluarga Sultan Fakhruddin sampai ia mangkat (b. 14-15).

Sultan Fakhruddin mangkat di rumah Johan Gerard van Angelbeek di Colombo. Van Angelbeek adalah ayah mertua Gubernur Ceylon, Willem Jacob van der Graaff. Van Angelbeek menggantikan Van der Graaff menjadi Gubernur, lalu ia menjadi Gubernur Belanda terakhir (ke-33) di Ceylon (lihat c. 33). Kematian Sultan Fakhruddin begitu mendadak: Van Angelbeek yang baru setahun menjabat sebagai Gubernur Ceylon mengajaknya makan siang di rumah dinasnya ${ }^{47}$ pada hari Minggu, 4 Rajab 1209 H (25 Januari 1795). Ia baru makan sepotong roti dan minum secangkir teh, tiba-tiba ia merasa pusing. Sultan Fakhruddin tidak jadi ikut makan, lalu ia dibaringkan di salah satu kamar di rumah itu. Akan tetapi, tak lama kemudian, pada pukul 13.30 siang, ia menghembuskan nafas terakhir (lihat c. 36).

Berdasarkan narasi surat Siti Hapipa, kematian Sultan Fakhruddin itu terlihat wajar. Sultan Fakhruddin seperti terkena serangan jantung. Tak ada keterangan yang membuat kita menaruh rasa curiga kepada tuan rumah.

Mataram yang sebagian besar beroposisi terhadap Susuhunan di Surakarta. Termasuk ke dalam kelompok ini 'pemberontak' Mas Guntur dan Mas Said (Ricklefs 1973: 191-192).

47 Lihat Ilustrasi 5. Percival (1803: 105) menggambarkan letak rumah dinas itu sebagai berikut: "In the centre of the principal street [of Columbo] is a very handsome and lofty house, which belonged to the Dutch governor, M. Van Angelbeck. At present it is the residence of General MacDowall, who commands our forces on the island". 
Malah, sebagai tanda dukacita, Van Angelbeek memberikan "beberapa pengasih[ $h$ ] [hadiah; Suryadi] yang tiada bole[ $h$ ] dibalas oleh" keluarganya (b. 18). Memang agak aneh juga bahwa Sultan Fakhruddin mangkat dalam usia yang masih relatif muda, yaitu kurang lebih 46 tahun (sekali lagi jika tahun kelahirannya kita hitung berdasarkan keterangan Buyers). Mungkin saja fisiknya melemah karena penderitaan lahir-batin selama 28 tahun berada di Ceylon, jauh dari sanak famili, rakyat, dan tanah tumpah darahnya. Kendatipun demikian, tampaknya Sultan Fakhruddin cukup dekat dengan pejabat-pejabat tinggi kolonial Belanda di Colombo, dan kedekatan itu (yang pada akhirnya menunjukkan kerenggangan) sangat mungkin karena faktor anak-anaknya yang kebanyakan terlibat dalam dinas ketentaraan Belanda (dan kemudian Inggris) seperti yang akan dijelaskan di belakang. Tentu orang besar seperti Van Angelbeek tidak akan mengundang sembarang orang makan ke rumahnya jika tidak dikenalnya secara dekat. Hubungan baik Sultan Fakhruddin dengan pemerintah VOC di Ceylon juga dapat terlihat dari kesediaan pemerintah kolonial Ceylon menaikkan gajinya, ditambah dengan tunjangan beras.

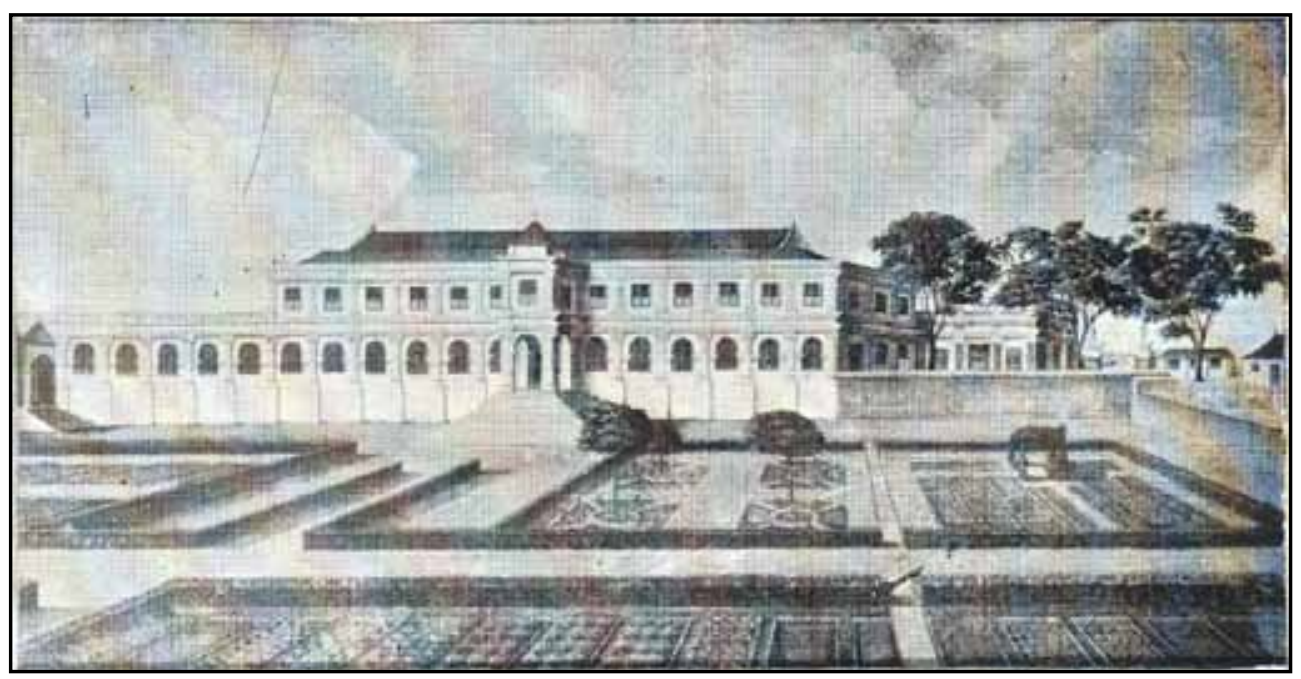

Ilustrasi 5: Rumah Dinas Gubernur Ceylon tempat Sultan Fakhruddin mangkat pada hari Minggu, 25 Januari 1795, pukul 13:30 (Brohier 1978: 89).

Entah memang karena gaji bulanan 50 riyal yang kemudian dinaikkan menjadi 100 riyal dan tunjangan "tiga puluh parah" beras itu masih tergolong kecil untuk standar hidup di Colombo pada masa itu atau karena gaya hidup (keluarga) Sultan Fakhruddin sendiri, rupanya Sultan masih kekurangan uang. Oleh karena itu, Sultan terpaksa sering meminjam uang kepada Kompeni dan juga orang lain. Pemerintah memotong gajinya 25 riyal per bulan untuk cicilan pinjaman dan utangnya (b. 18-19). Ketika mangkat, Sultan Fakhruddin masih punya utang yang cukup besar: "lima ribu riyal" (b. 19). Dalam suratnya Siti Hapipa mengeluh betapa utang yang dibuat suaminya kini menjadi beban 
berat bagi keluarganya.

Tampaknya biaya hidup di kota Colombo pada masa itu memang tergolong cukup mahal. Seorang pangeran dari Bacan yang dibuang VOC ke ibukota Ceylon itu juga mengeluh tentang mahalnya biaya hidup di sana: " $[\mathrm{H}]$ amba keduanya [berdua bersaudara; Suryadi] diam duabelas tahun di Tanah Selang di dalam Negeri Kolombo ini, hamba keduanya hidup dengan mudarat dari sebab sedikit gaji serta barang2pun sangat mahal [...]", demikian tulis Prins Meor Bacan Sadar Alam dan saudaranya Ja[o]guguh Bacan Kaicil Naim al-Din dalam suratnya kepada Gubernur Jenderal Arnold Alting di Batavia pada tahun $1792 .{ }^{48} \mathrm{Hal}$ itu senada dengan keterangan Percival.

The expence of living at Columbo is much more considerable than might be expected. Every thing in Ceylon in general is indeed deader than on the continent of India, from whence most of the articles in use are imported, and the expence of carriage has consequently to be added to their original cost. Horses and servants are particularly expensive. To keep one horse at Columbo will cost as much as to keep two at Madras. Servants' wages are also rearly double, as it is the custom to bring them from Bengal and Madras, and they, as well as their masters, must pay dearer for their clothes and food than in other native countries where these articles are produced. (Percival 1803: 119).

Percival juga menulis tentang besarnya fluktuasi nilai tukar mata uang di Colombo yang sangat dipengaruhi oleh ketersediaan emas dan perak di sana (Percival 1803: 118). Anehnya, riyal $^{49}$ tidak disebut-sebut dalam deskripsinya mengenai jenis-jenis mata uang yang berlaku di ibukota Ceylon itu, baik pada zaman VOC maupun setelah Inggris memerintah di Ceylon.

The current coin here, as well as in the rest of the European dominions on the island, consisted on the arrival of the English, of rix-dollars, a nominal coin, like our pound sterling, valued at a certain quantity of copper money. There were besides several smaller copper coin, called pice or stivers, half-pice, and dudies. Four pice or two dudies went to a fanam, and seven fanams to a rix-dollar. This proportional value of the coins has however been altered, and new regulations established since the island has come into our possession. There is now current a new coinage of double and single pice and half-pice, made by our East Indies Company. A pice is about a halfpenny sterling; four pice go to a fanam, and twelve fanams to a rix-dollar, or, as it is usually called by our people, a copper rupee. This latter coin goes for about two shillings sterling; and four of them are equivalent to a star pagoda of madras gold coin worth eight shillings sterling. (Percival 1803: 117-118).

Kematian Sultan Fakhruddin yang tiba-tiba telah membuat Siti Hapipa dan anak cucunya kehilangan pilar ekonomi keluarga. Ia tidak mampu lagi membayar utang-utang yang ditinggalkan almarhum suaminya yang cukup

\footnotetext{
48 Dikutip dari naskah Leiden Cod.Or.2240-Ia 11 [no.71], baris 14-15 (lihat c. 4) (garis bawah oleh Suryadi).

49 Sering juga ditulis real (batu), yang menurut Carey (2007: 837) adalah "(an old mutilated silver coin, usually Portuguese cruzados or German crowns [fracas], in general circulation, but not issued by the Dutch Government)". Sekitar awal abad kesembilan belas, satu riyal (atau real) nilainya sama dengan 2,40 guilders (gulden). Lebih jauh mengenai jenisjenis mata uang pada zaman itu, lihat Netscher dan Van der Chijs (1864: 76-88, 225-230).
} 
banyak jumlahnya. Jangankan untuk membayar utang, biaya untuk makan sehari-hari saja tidak cukup karena kecilnya tunjangan yang diberikan pemerintah kolonial Inggris (b. 25-26). Dari narasi empat surat Melayu dari Ceylon yang saya teliti (c. 4) dapat terlihat bahwa dalam hal pemberian gaji (atau tunjangan) kepada para eksil, Belanda ternyata lebih pemurah daripada Inggris. Kebijakan Inggris untuk mengurangi jumlah gaji dan tunjangan kepada para eksil warisan Belanda telah membuat keluarga para eksil itu, termasuk keluarga Siti Hapipa, terancam bangkrut. Rumah dan harta milik mereka yang masih ada terancam disita oleh pemerintah kota Colombo. Di bawah kekuasaan Inggris, siapa yang tidak mampu lagi membayar utangutangnya akan menghadapi risiko: rumahnya dilelang oleh pemerintah untuk membayar utang-utangnya dan ia dipenjara. Siti Hapipa menulis dalam suratnya bahwa "[...] bukan kepada orang kecil" saja hukum seperti itu diterapkan, tetapi juga "kepada tuan2 dan raja2 orang ter[r]buang pun sudah berlaku yang demikian rupa $<\mathrm{h}>$ " (b. 24-25).

Oleh sebab itulah, di akhir suratnya yang dikirim kepada Gubernur Jenderal Hindia-Belanda di Batavia yang waktu itu dijabat oleh Albertus Henricus Wiese (1805-1808) (Stapel 1941: 74-75), Siti Hapipa memohon kepada Kompeni agar berkenan membantu membayar utang-utang almarhum suaminya di Colombo. Sebagai kompensasinya ia bersedia mengabdi kepada Gubernur Jenderal di Batavia. Tidak ada penjelasan dari Siti Hapipa dalam suratnya bahwa ia dan keluarganya ingin kembali ke Gowa.

\section{Keluarga Sultan FakHRUdDin DALAM PUSARAN POlitiK KOlONIAL DI CEYLON}

Setahun setelah Sultan Fakhruddin mangkat Ceylon diambil alih oleh Inggris dari kontrol Belanda (1796) (lihat c. 33). Pergantian rezim kolonial di Ceylon menyebabkan terjadinya perubahan berbagai regulasi, yang pada gilirannya berdampak kepada masyarakat luas, tidak terkecuali orang-orang buangan Belanda seperti keluarga Sultan Fakhruddin. Siti Hapipa dan anak-cucunya menghadapi cobaan berat di bawah kekuasaan pemerintah kolonial Inggris di Ceylon. Mereka tidak lagi menerima gaji bulanan dari Inggris seperti "besar sayang [yang] diberi oleh" Belanda dulu, melainkan hanya tunjangan yang sangat kecil sebesar "harganya [hanya] satu parah dua<h> riyal harganya beras" (b. 26).

Siti Hapipa menulis dalam suratnya : [E]mpat orang anak hamba yang laki-laki diambil masuk di dalam pekerjaan Kompeni oleh Tuan-tuan Inggiris" (b. 21). Ia tidak merelakan anaknya dibawa pergi oleh Inggris, namun ia tidak dapat mencegahnya karena takut (b. 22). Tampaknya yang dimaksud dengan 'pekerjaan Kompeni [...] Inggiris' dalam kalimat Siti Hapipa adalah bagian dari pasukan militer kolonial Inggris yang terdiri dari orang Melayu dan pribumi lainnya. Pasukan inilah yang kemudian mengalami transformasi menjadi apa yang disebut "the Ceylon Rifle Regiment" (1805-1873)..$^{50}$ Anggota pasukan Melayu itu terdiri dari berbagai suku bangsa dari Nusantara seperti Jawa,

50 Lebih jauh tentang “The Ceylon Rifle Regiment”, lihat Hussainmiya (1990). 
Madura, Bugis (seperti anak-anak Sultan Fakhruddin), dan Melayu. Mereka adalah bagian dari garnisun pasukan kolonial Inggris di Ceylon yang sangat diandalkan di medan perang karena keberanian mereka.

They are all bold, warlike, and prepared for the most desperate enterprizes; they hear the commands of their superiors with the most profound reverence, and yield implicit obedience to their most rigorous orders. [...] From their natural intrepidity and hardiness, they are well calculated to become very useful and serviceable troops if properly officered and commanded. [...] Along with their other arms they always wear their kreese [keris] or poisoned daggers by their sides: in the heat of an engagement they often throw down their musket and bayonet, and rushing upon the enemy with these kreeses carry terror and destruction wherever they come. [...]. Accustomed to depend upon their courage, and avenge their own cause, there is more independence of spirit, and more appearance of a lofty intrepidity found among them, than among any other of the servile tribes of the east. [...] When a Malay is pressed in battle, he will sooner be slain, or kill himself, than surrender his kreese to the enemy.[...]. Brave, ferocious, and desperate to the last degree, on any occasion that requires blood to be shed; cruel and revengeful in their wrath, beyond what human nature can almost be thought capable of, they are looked upon with horror by the effeminate and timid Indians. I have often had occasion to observe these sentiments in the natives of Ceylon, who start affrighted on accidentally meeting a Malay soldier. (Percival 1803: 154-155, 164-165).

Pada tahun 1782 pemerintah kolonial Belanda di Ceylon mendaftarkan orang-orang Melayu eksil ke dalam dinas ketentaraan mereka, kecuali yang dikategorikan sebagai residivis (Hussainmiya 1987: 41; Nuhman 2007: 21). Ketika Ceylon diambil alih oleh Inggris, keberadaan pasukan Melayu itu terus dipertahankan oleh Gubernur Frederick North (1798-1805), sebuah kebijakan yang kemudian agak ditentang oleh suksesornya, Thomas Maitland (1805-1811) (Hussainmiya 1990: 67-68). North berusaha merangkul pasukan Melayu warisan Belanda itu ke dalam dinas militer Inggris, memperbesar jumlah personelnya, melengkapinya dengan seragam dan persenjataan yang lebih baik, dan mengangkat pemimpin baru untuk mereka yang bernama Colonel Champagne (Percival 1803: 163-164). Alasan North yang utama, mengutip kata-kata Hussainmiya (1990: 57), adalah karena "most accounts of the invasions stress the fact that it was only from the Malay troops that the British received any opposition".

Atas perintah Gubernur North seluruh orang Melayu di Ceylon - melalui pengumuman resmi Pemerintah tanggal 13 Maret 1799 - dihimbau untuk tunduk dan mau bekerja sama dengan pemerintahan yang baru. Hasilnya: lebih dari $75 \%$ orang Melayu yang tinggal di sana diterima menjadi anggota pasukan militer pribumi Inggris (Husainmiya 1990: 73). Politik North ini ternyata besar manfaatnya bagi pemerintah kolonial Inggris di Ceylon. Demikianlah umpamanya, kemenangan gemilang pasukan Inggris dalam Perang Polygar di India Selatan (sekarang masuk wilayah Tamil Nadu) tahun 1800 tak lepas dari keberanian Resimen Melayu ini di medan pertempuran. ${ }^{51}$

$51 \quad$ Kemenangan itu dimungkinkan oleh ikut sertanya sekitar 500 orang Madura (kebanyakan berasal dari Sumenep) yang terkenal sangat pemberani dalam pasukan Melayu 
Seperti disebutkan Buyers, ikut dalam peperangan di Polygar itu salah seorang anak Sultan Fakhruddin, yaitu Karaeng Abdullah, yang menjabat sebagai kapten Resimen Melayu di Ceylon. Ia tewas dalam peperangan itu (lihat kutipan di atas), hal yang juga dikonfirmasikan oleh Siti Hapipa dalam suratnya (b. 21-22). Berdasarkan sumber-sumber arsip kolonial VOC tentang Ceylon, Hussainmiya (1990: 69) juga mengatakan bahwa anak Sultan Fakhruddin yang lain, Yusuf (anak nomor 1 dalam daftar Buyers) yang disebut "Captain Usop Gowa", juga ikut dalam Perang Polygar. Ia bernasib sama seperti saudaranya, Karaeng Abdullah: tewas dalam peperangan di wilayah India Selatan itu.

Dengan politik merangkul Gubernur North berharap pula pasukan Melayu itu tidak lagi membahayakan Inggris di Ceylon. Memang sudah beberapa kali pasukan Melayu yang masih setia kepada tuan Belandanya menyerang tentara Inggris. ${ }^{52}$ Yang paling tragis adalah kasus desersi yang mereka lakukan dalam invasi pertama pasukan Inggris terhadap Kerajaan Kandy di awal 1803 (Anglo-Kandyan War). Seperti dicatat Buyers dalam kutipan di atas, dua orang anak lelaki Sultan Fakhruddin ikut dalam peperangan itu. Mereka tetap setia kepada Inggris yang menjadi pimpinan mereka ketika pasukan Mayor Davie menderita kekalahan telak melawan pasukan Kerajaan Kandy (lihat uraian di bawah). Mereka adalah Karaeng Muhammad Nuruddin dan Karaeng Saifuddin, keduanya berpangkat kapten dalam Resimen Melayu Inggris di Ceylon. Sebelumnya, di zaman pemerintahan Belanda, saudara tiri mereka (lain ibu), Karaeng Sangunglo, melakukan desersi dan menyeberang ke pihak Kandy. Diduga ia adalah bagian dari pasukan Melayu Belanda yang membelot ke pihak Kandy dalam perang VOC - Kandy tahun 1761/62 karena alasan tidak mampu membayar pinjaman kepada atasan mereka (Hussainmiya 1990: 69). Pada awal abad kesembilan belas sejumlah orang Melayu - tentara pribumi dan budak - melarikan diri ke wilayah Kandy karena perlakuan buruk Belanda (Pridham 1849: I, 152). Mereka inilah yang oleh Hussainmiya (1990: 68-69) disebut sebagai “the Kandyan Malays'. Menurut Hussainmiya, kasus desersi banyak anggota pasukan Resimen Melayu Inggris dalam invasi ke Kandy pada tahun 1803 antara lain disebabkan juga oleh faktor komunitas Melayu Kandy ini. Dengan mengutip Powell, Cordiner, Methley, dan Greevings yang juga menyebut-nyebut nama anak-anak Sultan Fakhruddin, Hussainmiya menulis:

Not all the Malays of the British garnison in Kandy went over to the Kandyans. Of the 700 Malays originally left behind in Kandy, there were still 250 who remained loyal to the British, who began their final exit from Kandy on June $24^{\text {th }}$ [1803] after

yang dilibatkan dalam pertempuran di Polygar itu. Salah seorang pemimpinnya bernama Pantasih, kakek Baba Ounus Saldin (1832-1906), intelektual dan pemuka kaum Melayu yang terkemuka di Ceylon (Hussainmiya 1991: 105).

52 Misalnya peristiwa Tricomalee pada malam 24 Agustus 1795, peristiwa penyergapan fregat Inggris L'Heroine di pantai Barberyn (26 mil dari Colombo), dan peristiwa penyerangan di dekat Mutuwal, tak jauh dari Colombo ketika bagian dari 300 pasukan Melayu di bawah pimpinan Kolonel Raymond menyerang pasukan Inggris yang sedang beristirahat di sana (Hussainmiya 1990: 57). 
Major Davie [the commander of the troops] had surrendered to the enemy. [A]mong those who were butchered by the Kandyans on the banks of the Mahaveli river at Watapuluwa were also a number of Malays who had refused to desert.

The desertions by the 'British Malays' during their stay in Kandy were largely brought about by the 'Kandyan Malays'. On behalf of their King they offered security and protection for their clan trapped in Kandy. The Kandyan King offered high rewards to Captain Noorden or Nouradin ['Karaeng Muhammad Nur ud-din' menurut Buyers] of the British Malay Regiment to come over to his side. [T] hese offers were made through the Commander of the Kandyan Malay army called Sanguylo (or Sangunglo), said to be a half-brother of Captain Noorden. But Noorden was a highly-principled man and a brave officer who immediately brought the ventures to the notice of his Commander and did all in his power to prevent desertions [...].

The Malay soldiers of the Kandyan King had proved themselves as a great source of strength to the Sinhalese during this war. It was they who led the Kandyan attack of $24^{\text {th }}$ June on the King's palace where the British garrison was stationed, and forced Commander Davie to surrender to the Kandyans and evacuate that post. [H]owever, the Kandyan Malay leader Sangunglo, was described as a 'fat and tall Malay prince' by Greevings, (who witnessed this attack) was killed during this attack by Major Davie. (Hussainmiya 1990: 68-69; garis bawah oleh Suryadi).

Hussainmiya (1990: 68-73) juga menyebut anak Sultan Fakhruddin yang lain yang masuk ke dalam pasukan Melayu binaan Inggris yang tidak disebut oleh Buyers: "[A]nother of his sons called Granine (Karaeng a title borne by Makassarese nobility) Sapinine was also in the British service" (hlm. 69). Tampaknya yang dimaksud adalah Karaeng Sapanang Yunusu (anak Sultan Fakhruddin nomor 6 dalam daftar Buyers di atas). Malah, dengan mengutip laporan R. Arbuthnot, Sekretaris Utama The Ceylon Government Gazette dalam surat kabar itu edisi 12 Januari (no. 45) 1803, Hussainmiya menyebutkan anak Sultan Fakhruddin, Karaeng Segeri (anak nomor 5 dalam daftar Buyers) juga ikut dalam pasukan Melayu Inggris di Ceylon. ${ }^{53}$ Dengan demikian, kenyataan sejarah yang sebenarnya tetap masih belum jelas karena Siti Hapipa sendiri menyebut hanya empat orang anak laki-lakinya yang "diambil masuk di dalam pekerjaan Kompeni oleh Tuan-tuan Inggiris", dan sayangnya ia tidak menyebutkan nama mereka. Sedangkan berdasarkan kajian sejarah yang dilakukan Hussainmiya dan Buyers, enam dari tujuh anak lelaki Sultan Fakhruddin masuk ke dalam pasukan Melayu Inggris di Ceylon. ${ }^{54}$ Lepas dari

$53 \quad$ Lihat Hussainmiya (1990: 157, Appendix I) yang mencatat tiga orang Bugis dalam senarai 24 orang 'the Malay officers of the Ceylon Malay Regiment in 1802'. Mereka adalah: "Nordin Go[w]ah (Rank: Captain; Date of Rank: 26-4-1801; Date of Commission: 9-121802); Crime [Karaeng] Segarry (Rank: Second Lieutenant; Date of Rank: 13-8-1801; Date of Commission: 9-12-1802); Crime [karaeng] Sapnam (Rank: Second Lieutenant; Date of Rank: 14-8-1801; Date of Commission: 9-12-1802)". Jelas ketiga orang itu adalah anak-anak Sultan Fakhruddin, yaitu Karaeng Yusuf, Karaeng Segeri Zainal Abidin, dan Karaeng Sapanang Yunusu (anak nomor 1, 5, dan 6 dalam daftar Buyers).

${ }_{54}$ Barangkali dua dari enam anak Sultan Fakhruddin yang bergabung dalam pasukan Melayu Inggris sebelumnya sudah bergabung dengan pasukan ini semasa Ceylon masih diperintah oleh Belanda, sehingga yang benar-benar "diambil masuk di dalam pekerjaan Kompeni oleh Tuan-tuan Inggiris" hanyalah empat orang anaknya, seperti disebutkan oleh Siti Hapipa dalam suratnya. Besar kemungkinan yang dua orang itu adalah yang terlibat dalam Perang Polygar tahun 1800 dan tewas di sana, yaitu Karaeng Yusuf ('Captain Usop Gowa') dan Karaeng Abdullah (anak nomor 1 dan 3 dalam daftar Buyers). 
itu, surat Siti Hapipa telah memperjelas kesimpangsiuran tentang jumlah sebenarnya anak Sultan Fakhruddin di Colombo. ${ }^{55}$

Terdapat beberapa laporan pandangan mata yang menggambarkan kehidupan komunitas Kandyan Malays di Kerajaan Kandy. Karaeng Sangunglo, anak Sultan Fakhruddin (anak tiri Siti Hapipa) yang membelot ke pihak Kandy semasih Ceylon berada di bawah perintah VOC adalah salah seorang tokoh penting komunitas Kandyan Malays itu. J.E. de Jonville yang menjadi penerjemah Duta Inggris MacDowall yang mengunjungi Kandy tahun 1800 mencatat bahwa komunitas Kadyan Malays tinggal di daerah Katukelle, sekitar satu mil dari istana Raja Kandy. Mereka tinggal di "little houses, very low, built of mud, each with a very narrow door and a window six inches square", demikian laporan De Jonville (1948: 17) mengenai bentuk rumah komunitas Melayu Kandy itu. De Jonville juga mengatakan bahwa Istana Kandy dijaga oleh tentara Melayu sewaan dengan seragam khusus dan senjata lengkap.

They are armed with guns of European make and ridiculously clad in the rags of the deserters or prisoners, taken since time immemorial form the Hollanders troops. Some newly dressed for the ceremony of the embassy had been clothed in red. They had also been given hats, some with four points and some with three, and several with none at all, but all were adorned with some fragments of imitation gold braid. The Colonel of the Corps was the most striking spectacle. His uniform was a long coat of afal falalas, and long trouser the whole enriched with imitation gold braid four inches wide. (De Jonville 1948: 18).

Pridham (1849: I, 132) melaporkan bahwa Kerajaan Kandy diperintah oleh raja-raja yang bengis dan barbar, yang membuat komunitas Melayu Kandy hidup dalam tekanan dan dilema. Di antara mereka ada yang ingin kembali ke pangkuan pemerintah kolonial Inggris, tapi tentu ada rasa ragu karena sudah dicap sebagai pembelot.

They would have returned to their former master and submitted to any punishment for their desertion rather than live as they did in continual fear the caprice of a despotic and barbarious court. (Pridham 1849: I, 132).

Hussainmiya (1990: 71) menduga ada bias kolonialisme dalam laporan Pridham itu dan oleh karenanya ia meragukan kebenarannya. Lepas dari itu, sejarah mencatat bahwa nasib komunitas Melayu Kandy, khususnya tentara Melayu pengawal Istana Raja, memang fluktuatif. Bintang mereka naik di masa kekuasaan Raja Nayakkar Kirthi Rajasinha (1747-1782) dan khususnya raja Kandy terakhir, Sri Vikrama Rajasinha (1798-1815). Ia banyak mengangkat orang asing, termasuk komunitas Melayu yang membelot dari pasukan Belanda dan Inggris, sebagai pasukan penjaga istananya, bahkan sebagai pengawal pribadinya, untuk melindungi dirinya dari intrik dan serangan musuh-musuh politiknya. Kepala Pasukan Melayu pengawal Istana Kandy dianugerahi gelar khusus yang disebut Muhandiram. Tentara Melayu digaji secara kontan,

55 Berbeda dengan Buyers (seperti dikutip), Hussainmiya (1990: 69) menyebutkan "he [Sultan Fakhruddin] had 5 sons and 3 daughters living in the island [Ceylon]". 
sementara rekan-rekan mereka yang berasal dari Malabar (Afrika) diberi bidang tanah untuk menunjang kehidupan keleuarga mereka. Kebijakan ini dibuat oleh Raja Nayakkar Kirthi Sri Rajasinha. Diperkirakan jumlah komunitas Melayu Kandy pada masa itu antara 200-300 orang dan hampir separohnya menjadi tentara bayaran Raja Kandy (Hussainmiya 1990: 70).

Tampaknya pasca Perang 103 pandangan komunitas Melayu Kandy berubah kepada penguasa kerajaan itu. Para pemimpin mereka tidak lagi menunjukkan loyalitas kepada Raja Kandy.

Subsequently, their leader became an antagonist of the Kandyan monarch and sided with his opponents, an action which almost cost the King's life. What could have caused this change? Perhaps they too began to resent the change in the attitude of the King, Sri Wikrema Rajasinghe [Sri Vikrama Rajasinha], who after the 1803 war began to adopt an unusually tough line towards his adversaries at court and suspected everyone of ploting against him. However, there may be some connection between the Malays turning away from him and his malicious treatment of the Noordeen brothers. (Hussainmiya 1990: 71).

Kalimat terakhir dalam kutipan di atas merujuk kepada nasib tragis dua anak lelaki Sultan Fakhruddin: Kapten Noordeen dan saudaranya, Karaeng Sapinine [Sapanang Yunusu]. Mereka dieksekusi oleh Raja Sri Vikrama Rajasinha yang murka karena keduanya tetap menunjukkan loyalitas mereka kepada Inggris. Kejadian itu berlangsung pada waktu Perang 1803 (The First Anglo-Kandyan War). Dalam pertempuran itu mereka saling berhadapan dengan saudara tiri mereka, Karaeng Sangunglo, yang berada di pihak Kandy. Karaeng Sangunglo, yang tidak berhasil membujuk kedua saudara tirinya itu untuk membelot ke pihak Kandy, akhirnya tewas di tangan Mayor Davie. Dengan mengutip James Cordiner (1807), Hussainmiya menggambarkan kisah tragis yang dialami oleh dua anak lelaki Sultan Fakhruddin yang masih hidup yang terjadi di Istana Kandy itu.

As the came to the royal presence, they declined to prostrate themselves in the customary manner, but instead saluted the King respectivefully, excusing themselves from performing the more formal abasement on the grounds of their royal status, their grandfather having been an independent ruler. Their temerity did not anger the King, who repeated his offer to the brothers to become 'princes' over Malays residing in his kingdom. Both brothers refused the offer, explaining that they had taken an oath to the King of England and that acceptance of this offer would be treachery, saying that they would live and die in their master's service. The King imprisoned them and 3 weeks later, again requested them to join him, but received the same reply once more. Following this, the King became very angry and ordered them to be executed.$^{56}$ Their bodies were denied decent burials and were said to have been thrown into the jungle to be devoured by wild beasts - an action that would have horrified and greatly offended his Malay-Muslim subjects. (Hussainmiya 1990: 71).

$56 \quad$ Buyers menyebutkan bahwa kedua anak Sultan Fakhruddin yang dieksekusi atas perintah Raja Sri Vikrama Rajasinha adalah Karaeng Nuruddin dan Karaeng Saefuddin. Dalam artikelnya (2001) Hussainmiya juga menyebut nama yang sama, tetapi dalam bukunya (1990: 70-71) ia menyebutkan bahwa yang dieksekusi adalah Karaeng Nuruddin dan Karaeng Sapanang Yunusu. 
Eksekusi terhadap Kapten Noordeen dan saudaranya, Karaeng Sapinine [Sapanang Yunusu] (atau Karaeng Saefuddin?) di Istana Kandy merupakan babak penutup rentetan kematian anak-anak lelaki Sultan Fakhruddin yang terbenam dalam pusaran politik dan peperangan atas nama kolonialisme Eropa di Ceylon dan India Selatan. Ayah mereka pun wafat di tanah pembuangan dalam keadaan bangkrut, tanpa sempat melihat kembali tanah tumpah darahnya di Gowa, Sulawesi, Hindia-Belanda.

\section{PENUTUP}

Surat Siti Hapipa yang dibahas dalam artikel ini adalah sebuah contoh sumber pribumi yang hampir terlupakan dalam studi sejarah kolonial Indonesia. Lewat analisis terhadap surat itu terbuka ruang kecil untuk melihat karakter sekaligus dampak global kolonialisme Eropa pada abad kedelapan belas dan sembilan belas. Apa yang saya sebut sebagai "surat-surat Melayu dari tanah pembuangan" agaknya perlu diteliti lebih lanjut oleh para sejarawan untuk memperkaya perspektif studi sejarah kolonialisme Indonesia. Pencarian sumber-sumber sejarah kolonial Indonesia tidak melulu mesti diarahkan ke dalam negeri dan Barat (khususnya Belanda), seperti selama ini terjadi, tetapi mestinya juga ke negara-negara Asia lainnya, seperti Sri Lanka, yang dulu sama-sama dijajah Belanda. Terdapat cukup banyak sumber-sumber pribumi Sri Lanka yang menggambarkan images mengenai Hindia-Belanda (Hussainmiya 1990: 140-149).

Surat Siti Hapipa merefleksikan kehidupan pada eksil di Ceylon yang tak lepas dari konstelasi sosial-politik dan ekonomi zaman itu. Surat tersebut juga cukup jelas menggambarkan hubungan para eksil dengan penguasa kolonial yang mengirim mereka ke tanah pembuangan. Rupanya keluarga Sultan Fakhruddin cukup menonjol dalam sejarah kolonialisme Belanda dan Inggris di Ceylon. Semua anak lelakinya terlibat aktif dan memegang posisi cukup tinggi (berpangkat kapten) dalam 'Resimen Melayu' garnisun militer kolonial Belanda dan Inggris di Ceylon. Hal itu pula yang menyebabkan mereka sering terbenam dalam pusaran politik kolonial pada masa itu. Hakikat diri mereka sebagai pribumi (natives) di satu pihak dan sebagai pasukan kolonial di lain pihak membuat mereka berada dalam dilema ketika Belanda ataupun Inggris mengikutsertakan mereka dalam invasi-invasi menumpas perlawanan kaum pribumi Ceylon, seperti terefleksi dalam pembelotan yang dilakukan oleh Karaeng Sangunglo.

Surat Siti Hapipa mengungkapkan sisi-sisi kehidupan kelompok manusia yang diasingkan oleh makhluk sesamanya yang lebih kuat (orang Eropa) ke tempat yang jauh dari tanah tumpah darahnya. Mereka adalah para 'pahlawan bangsa' yang kisah kehidupannya amat jarang tersua dalam buku-buku sejarah Indonesia. Perjuangan mereka melawan sang kolonialis terus berlanjut walau mereka telah dibuang di negeri yang jauh dan menderita lahir batin di tempat pengasingan. ${ }^{57}$

${ }^{57} \quad$ Saya telah selesai mentransliterasikan empat surat Melayu dari Ceylon yang disenaraikan dalam catatan 4 (lihat: http:/ / mcp.anu.edu.au/, website Malay Concordance Project, Australian National University, Canberra). Isi surat-surat itu merefleksikan penderitaan lahir 
Pada tahun 1995 pemerintah Republik Indonesia mengangkat Syekh Yusuf al-Makassari yang wafat di Zandvliet Afrika Selatan pada tanggal 23 Mei 1699 sebagai pahlawan nasional (Triyana 2008). Pada bulan Oktober 2005 Syekh Yusuf dianugerahi pula penghargaan Oliver Thambo, yaitu penghargaan sebagai Pahlawan Nasional Afrika Selatan (Osa 2005). Artikel ini mengungkapkan satu orang lagi kandidat 'pahlawan nasional Indonesia seberang lautan' seperti Syekh Yusuf al-Makassari. Ia adalah Kapten Karaeng Sangunglo, salah seorang anak Sultan Fakhruddin yang telah memimpin Komunitas Melayu Kandy dan bahu-membahu dengan rakyat Kandy (Ceylon) melawan kolonialis Belanda dan Inggris. Ia tewas di Kandy dalam sebuah perjuangan menentang penguasaan kelompok manusia oleh kelompok manusia lainnya. Seperti halnya dengan Afrika Selatan, Indonesia dan Sri Lanka potensial untuk merajut hubungan bilateral yang lebih akrab dengan menggunakan 'tali' sejarah kolonial di masa lampau. Sesungguhnya 'tali' sejarah itu tidak pernah putus: sekarang terdapat 50.000 jiwa "the Sri Lankan Malays" di Sri Lanka. Jumlah itu adalah 0.3\% dari total penduduk Sri Lanka atau 0.4\% dari total warga Muslim di negara itu (Hussein 2007: 408). Nenek moyang mereka berasal dari berbagai suku bangsa di Nusantara yang dulu, karena berbagai alasan, dibawa oleh kolonialis Belanda ke Ceylon. Mereka adalah bukti hidup dari keangkuhan kolonialisme Eropa di zaman lampau tetapi kini mestinya menjadi berkah bagi penguatan hubungan antarbangsa Asia, dalam hal ini Indonesia - Sri Lanka.

\section{DAFTAR PUSTAKA}

Ab Karim, Ab Razak. 2001. "Penggunaan kaligrafi dalam warkah-warkah Melayu: suatu kajian", Jurnal Filologi Melayu 9: 730-782.

Adam, Ahmat. 1992. Sejarah dan bibliografi akhbar dan majalah Melayu abad kesembilan belas. Kuala Lumpur: Penerbit Universiti Kebangsaan Malaysia.

Andaya, Leonard. 1981. The heritage of Arung Palakka: the history of South Sulawesi (Celebes) in the seventeenth century. The Hague: Nijhoff.

An officer, late of the Ceylon Rifles (H.S.). 1876. Ceylon: a general description of the island, historical, physical, statistical, containing the most recent information. Vol. 1. London: Chapman and Hall.

Boomgaard, Peter (red.). 2007. A world of water: rain, rivers and seas in Southeast Asian histories. Leiden: KITLV Press.

Brohier, R.L. 1978. Links between Sri Lanka and the Netherlands. Colombo: The Netherlands Alumni Association of Sri Lanka.

Caldwell, Ian. 1995. "Power, state and society among the pre-Islamic Bugis", Bijdragen tot de Taal-, Land- en Volkenkunde 151-3: 394-421.

Carey, Peter. 2007. The power of prophecy: Prince Dipanegara and the end of an old order in Java, 1785-1855. Leiden: KITLV Press.

batin para bangsawan eksil di Ceylon. Hampir pasti hal yang sama juga dialami oleh mereka yang dibuang Belanda ke negeri-negeri lain pada zaman kolonial. 
Chambert-Loir, Henri. 1985. Ceritera asal bangsa jin dan segala dewa-dewa. Bandung: Penerbit Angkasa dan Ėcole Française d'Extrême Orient.

Chambert-Loir, Henri. 2004. Kerajaan Bima dalam sastra dan sejarah. Jakarta: Kepustakaan Populer Gramedia. (Naskah Dokumen Nusantara 19).

Chambert-Loir, Henri dan Siti Maryam Salahuddin. 1999. Bo' Sangaji Kai: catatan Kerajaan Bima. Jakarta. EFEO dan Yayasan Obor Indonesia. (Seri Naskah Dokumen Nusantara 18).

Cummings, William P. 2007. A chain of kings: the Makassarese chronicles of Gowa and Talloq. Leiden: KITLV Press. (Bibliotheca Indonesica 33).

De Jonville, J.E. 1948. "Narrative of a journey to Kandy made on the occasion of the Embassy of Major General MacDowall in 1800", Journal of the Royal Asiatic Society, Ceylon Branch 38 (105): 1-21.

Erkelens, E. 1897. “Geschiedenis van het Rijk Gowa”, Verhandelingen van het Bataviaasch Genootschap van Kunsten en Wetenschappen 50: 81-121.

Gallop, Annabel Teh. 2002. Malay seal inscriptions: a study in Islamic epigraphy from Southeast Asia. (Disertasi, SOAS, University of London). 3 vol.

Gericke, J.F.C. dan T. Roorda. 1901. Javaansch-Nederlandsch handwoordenboek. Amsterdam: Johannes Müller. 2 jilid.

Haris, Tawalinuddin. 2006. "Kesultanan Bima di Pulau Sumbawa", Wacana 8-1 (April): 17-31.

Hussainmiya, B.A. 1987. Lost cousins: the Malays of the Sri Lanka. Bangi: Penerbit Universiti Kebangsaan Malaysia.

Hussainmiya, B.A. 1990. Orang rejimen: the Malays of the Ceylon Rifle Regiment. Bangi: Penerbit Universiti Kebangsaan Malaysia.

Hussainmiya, B.A. 1991. “Baba Ounus Saldin: an account of a Malay literary servant of Sri Lanka", Journal of the Malayan Branch of The Royal Asiatic Society 64-2: 103-134.

Hussainmiya, B.A. 2001. "Malay heroism in Sri Lanka", Borneo Bulletin (Saturday, 11 August).

Hussein, Asiff. 2007. Sarandib: an ethnological study of the Muslims of Sri Lanka. Dehiwala: A.J. Prints (Pvt) Ltd.

Kratz, E.Ulrich. 2006. “Like a fish grasping for water: the letters of a temporary spouse from Bengkulu", Indonesia and the Malay World Vol. 34, No. 100 (November): 247-280.

Matthes, Benjamin Frederick. 1883. Makassarsch geschrift bevattende de oudste geschiedenis van Gôwa, Tâlló en eenige andere rijken van Zuid-Celebes. Amsterdam: C.A. Spin \& Zn.

Nain, Sjafnir Aboe. 2004. Naskah Tuanku Imam Bonjol. Padang: PPIM.

Nelson, W.A. 1984. The Dutch forts of Sri Lanka: the military monuments of Ceylon. Edinburg: Canongate.

Netscher, E dan J.A. van der Chijs. 1864. “De munten van Nederlandsch-Indië, beschreven en afgebeeld", Verhandelingen van het Bataviaasch Genootschap van Kunsten en Wetenschappen 32-2: 1-230.

Nuhman, M.A. 2007. Sri Lankan Muslims: ethnic identity within cultural diversity. Colombo: International Centre for Ethnic Studies. 
Osa. 2005. "Meneladani perjuangan Syekh Yusuf al-Makassari al-Bantani", Republika (Jumat, 14 Oktober).

Patunru, Abd. Razak Daeng. 1993. Sejarah Gowa. Ujung Pandang: Yayasan Kebudayaan Sulawesi Selatan.

Percival ESQ, Robert. 1803. An account of the island of Ceylon, containing its history, geography, natural history, with the manners and customs of its various inhabitants; to which is added, the journal of an embassy to the court of Candy. London: C and R. Baldwin.

Philalethes. 1817. The history of Ceylon from the earliest period to the year MDCCCXV; with characteristics details of the religion, laws, and manners of the people and a collection of their moral maxims and ancient proverbs. London: Joseph Mawman.

Pridham, Charles. 1849. An historical, political and statistical account of Ceylon and its dependencies. Vol. I. London: Boone.

Ricklefs, M. 1973. Jogjakarta under Sultan Mangkubumi, 1749-1792: a history of the division of Java. Part 1. (PhD dissertation, Cornell University).

Robson, S.O. 1969. Hikayat Andaken Panurat. The Hague: Nijhoff.

Schrikker, Alicia. 2007. Dutch and British colonial intervention in Sri Lanka, 17891815: expansion and reform. Leiden: Brill.

Stapel, F.W. 1941. Gouverneurs-Generaal van Nederlandsch-Indië. Den Haag: Stockum.

Suryadi. 2007a. “Warkah-warkah Sultan Buton Muhyiuddin Abdul Gafur kepada Kompeni Belanda, koleksi Universiteitsbibliotheek Leiden", Sari 25: 187-239.

Suryadi. 2007b."Surat-surat Sultan Buton, Dayyan Asraruddin dan Kaimuddin I, koleksi Universiteitsbibliotheek Leiden, Belanda", Jurnal Humaniora 19-9 (Oktober): 284-301.

Suryadi. (akan terbit). "Surat-surat Sultan Bima Abdul Hamid Muhammad Syah kepada Kompeni Belanda koleksi Universiteitsbibliotheek Leiden". (EFEO Jakarta; revisi makalah Simposium Internasional Pernaskahan Nusantara XI, Bima, Nusa Tenggara Barat, Indonesia, 26-28 Juli 2007).

Triyana. 2008. "Syekh Yusuf al-Makassari al-Bantani: ulama pejuang”, Jurnal Nasional (Minggu, 6 April).

Van den Belt, Albert. 2008. Het VOC-bedrijf op Ceylon: een voorname vestiging van de Oost-Indische Compagnie in de 18de eeuw. Zutphen: Walburg Press.

Van Ronkel, Ph.S. 1921. Suplement catalogues der Maleische en Minangkabausche handschriften in de Leidsche Universiteits-bibliotheek. Leiden: Brill.

Vikør, Lars. 1988. Perfecting spelling: spelling discussions and reforms in Indonesia and Malaysia, 1900-1972. Dordrecht/Providence: Foris.

Voorhoeve, P. 1964. “A Malay scriptorium”, di dalam: John Bastin dan R. Roolvink (red.), Malayan and Indonesian Studies: Essay presented to Sir Richard Winsted on his eighty-fifth birthday, hlm. 256-266. Oxford: Oxford University Press.

Wibisono, Singgih dan Stuart Robson. 2002. Javanese-English dictionary. Singapore: Periplus. 
Wieringa, Edwin. 1998. Catalogue of Malay and Minangkabau manuscripts in the Library of Leiden University and other collections in the Netherlands. Vol. 1. Leiden: Legatum Warnerianum in Leiden University Library.

Wieringa, Edwin. 2003. “Syair Baba Kong Sit: suatu syair bersifat kewartawanan tentang kes penyelundupan seorang Tionghowa pada tahun 1842", Jurnal Filologi Melayu 11: 45-59.

Winstedt, R.O. 1963. An unabridged Malay - English dictionary. Cetakan ketiga. Kuala Lumpur: Marican and Sons. (Cetakan pertama 1958).

Wojowasito, S. 2003. Kamus umum Belanda-Indonesia. Jakarta: Ichtiar Baru dan Van Hoeve.

Zandvliet, Kees. 2002. The Dutch encounter with Asia, 1600-1950. Zwolle: Rijksmuseum Amsterdam and Waanders Publishers. 